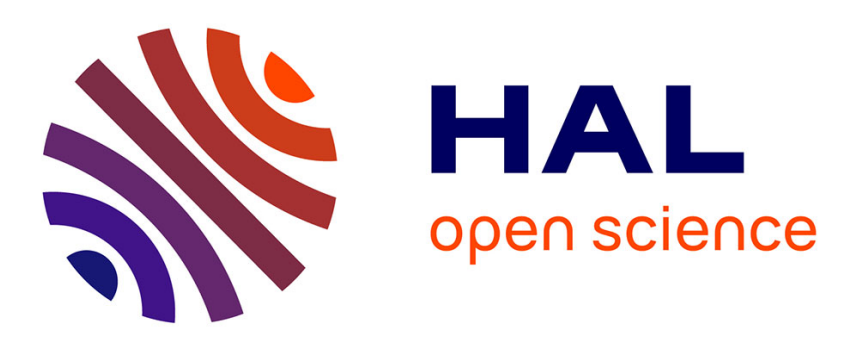

\title{
Sea-river shipping competitiveness and its geographical market area for the Rhône-Saône corridor
}

\author{
Charles Lopez
}

\section{To cite this version:}

Charles Lopez. Sea-river shipping competitiveness and its geographical market area for the Rhône-Saône corridor. Journal of Transport Geography, 2008, 16 (2), pp. 100-116. 10.1016/j.jtrangeo.2007.04.003 . halshs-00304325

\section{HAL Id: halshs-00304325 \\ https://shs.hal.science/halshs-00304325}

Submitted on 24 Jul 2008

HAL is a multi-disciplinary open access archive for the deposit and dissemination of scientific research documents, whether they are published or not. The documents may come from teaching and research institutions in France or abroad, or from public or private research centers.
L'archive ouverte pluridisciplinaire HAL, est destinée au dépôt et à la diffusion de documents scientifiques de niveau recherche, publiés ou non, émanant des établissements d'enseignement et de recherche français ou étrangers, des laboratoires publics ou privés. 


\title{
SEA-RIVER SHIPPING COMPETITIVENESS AND ITS GEOGRAPHICAL MARKET AREA FOR THE RHÔNE- SAÔNE CORRIDOR.
}

\author{
Lopez Charles $^{\mathrm{a} 1}$ \\ Journal of Transport Geography, 2008, volume 16, issue 2, pp. 100-116 \\ a Laboratoire d'Economie des Transports, CNRS UMR n5593; Université Lumière Lyon 2. \\ Lyon, France, march 2006
}

\begin{abstract}
:
The concept of sea-river shipping is simple: a single vessel sails both coastal and inland waters. Thus, seaport transhipment is avoided resulting in lower transport costs. However, this concept is limited to certain transport waterways. On the Rhône-Saône corridor, sea-river shipping can directly connect inland ports with Mediterranean seaports. The absence of transhipment raises the issue of the competition/complementarity between sea-river shipping and a transport chain associating inland and maritime transport. Sea-river vessels must abide by certain specifications, such as draught, height and length, all related to the navigational restrictions on rivers and canals. The question is: at what threshold, in terms of tonnage, are sea-river vessels more efficient than "barge+shortsea" transport service? After addressing this question, we determine, for different ports of the Rhône-Saône corridor, the competitive navigational area of sea-river shipping.
\end{abstract}

KEYWORDS: multi-modal transport chain, sea-river/short sea shipping, production costs, Rhône-Saône corridor

\section{INTRODUCTION}

The purpose of this study is to examine the competitiveness of sea-river shipping departing from the RhôneSaône basin. This analysis can be divided in two parts. Firstly, we define the tipping point between two transport alternatives: sea-river shipping and "river + sea" transport. Secondly, we determine the competitive geographical range of sea-river shipping, departing from different ports of the Rhône-Saône waterway.

Sea-river shipping is a form of short-sea transport and an interesting multi-modal transport. Its concept is simple: one vessel sails both coastal and inland waters. Sea-river ships can connect the hinterland with overseas destinations without the need for an intermediate transhipment. As a result, transport costs are lowered and the risk of damage due to handling is reduced. Nevertheless, sea-river shipping has not been significantly developed in Europe (Rissoan, 1994, 1995). Substantial traffic volumes are only found on a very limited number of routes (e.g. Rhine; some Russian waterways). In France, it is restricted to a very limited number of waterways, such as the Seine or the Rhône-Saône basin. On the Rhône-Saône corridor, sea-river shipping can directly connect inland ports with Mediterranean seaports. Then, it offers "Rhône valley-Mediterranean" logistics.

Rissoan (1987) tries, for different products, to define the competitive navigational area of sea-river shipping (including river and maritime trips). Konings and Ludema (2000) evaluate the opportunities for sea-river shipping on the United Kingdom - Germany corridor (Rhine). They examine its competitiveness with regard to a number of alternative transport modes. Nonetheless, there is no study which calculates the volume that divides the transport market between sea-river shipping and a "river + sea" alternative. A reasonable question arises: at which threshold, in terms of tonnage, are sea-river vessels more efficient than barge+shortsea transport service? Comparing the returns to scale of each transport chain, we define this tipping point. The costs production function is taken from Cullinane - Khanna (2000) and Stopford (2002).

After addressing this question, we determine, for different ports of the Rhône-Saône corridor, the maximum sea trip that is efficient for a sea-river vessel (as a function of tonnage). After Rissoan (1987), we define the competitive navigational area of sea-river shipping. Our specific contribution is to consider the nautical access offered by inland ports along the Rhône and the Saône.

The development of sea-river shipping on the Rhône-Saône basin began recently. Sea-river vessels have been operating on this waterway, since 1977, the date of the Tricastin contract. The decision to build a nuclear power station in Tricastin attracted the first sea-river vessels. This construction required the transportation of heavy goods (many of them were very sensitive to handling). Hence, the suppression of transhipment reduced the risk of damage. This was a decisive factor in the choice of sea-river transport. In order to avoid travelling empty on the return journey, sea-river operators searched for potential demand of freight for Mediterranean ports. Thus, the

${ }^{1}$ Corresponding author: Laboratoire d'Economie des Transports, Institut des Sciences de l'Homme

14, av Berthelot 69363 Lyon cedex 07 France

Tel: +33 (0)4 72726436 - Fax: +33 (0)4 72726448

E-mail address: charles.lopez@let.ish-lyon.cnrs.fr 
exportation of cereals to Southern Italy began. Since the first year of operation, the annual tonnage transported by sea-river vessels has been multiplied by 70 . Today, the annual volume is almost one million tons.

\title{
2 THE SEA-RIVER EQUATION
}

As we can see in the scheme below (Rodrigue et al. 1998), sea-river ships are able to bypass maritime ports and go directly from one inland port to another (in a different inland river system). In our case, sea-river shipping can link the Rhône-Saône waterway with Mediterranean ports. For example, Lyon and Barcelona can be directly connected without transhipment between the river and maritime sections.

Figure 1: Impacts of Sea-river shipping on a transport chain

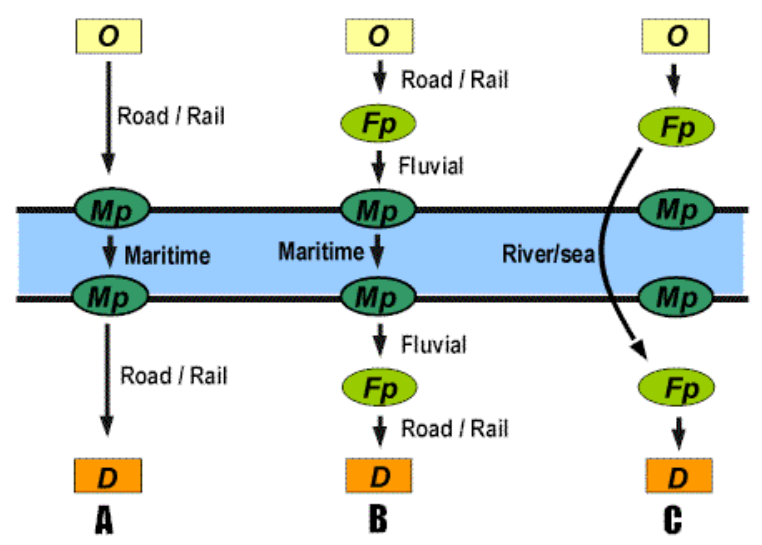

\author{
0 : Origin. \\ D : Destination. \\ Mp : Maritime ports. \\ Fp : Fluvial ports = inland ports.
} (Mp).

(A). A standard transport chain involving road or rail transportation and intermodalism at two maritime ports

(B) When possible, a transportation chain can use fluvial ports (Fp) with shipment being consolidated or broken down at maritime ports.

(C) With sea- river shipping, it is possible to bypass maritime ports and go directly from an inland port to another.

Source: http://www.geog.umontreal.ca/Geotrans/fr/ch3fr/conc3fr/fluvialmaritimefr.html, Rodrigue, J-P et al. (2006) Site Web Géographie des Transports, Hofstra University: Department of Economics and Geography.

We can compare sea-river shipping with different transport chains associating one inland link (river, rail or road) with one maritime link. We know that of the three land transport modes, road is the most expensive, river is the cheapest while rail ranks between the two. For inland transport, we set the sea-river shipping in the worst cost situation. It will be compared with the cheapest of the three land alternatives: river transport. Hence, we wish to study the competition/complementarity between a sea-river alternative and a "river + sea" transport chain. These two transport chains are quite similar in terms of hauling capacities. In addition, comparing transport modes with different carrying capacities seems less relevant. In order to conduct an unbiased study, the scales of operations (in terms of transported tonnage) must be comparable. The cargo capacity of a typical sea-river vessel is about 2,000 tons while a truck's hauling capacity is approximately 30 tons. Comparing sea-river shipping with a transport chain including road transport could be compared to adding apples to oranges. Concerning the rail link, we are faced with the absence of cost function's data (French railways operators).

The quality of the inland waterway network is a decisive factor in the development of sea-river transport. Sea-river vessels must obey certain specifications such as draught, height and length, all related to the navigational restrictions on rivers and canals. These restrictions limit sea-river vessel's size. However, sea-river transport is economically attractive when it can solve the sea-river equation defined by Rissoan (1987). Sea-river transport offers more expensive freight charges than river or maritime services on each isolated transport leg. It presents two additional costs, one related to the river part and the other one to the sea. On the one hand, sea-river shipping causes some extra costs, but on the other hand, users can save money with the transhipment suppression. In order to make sea-river shipping viable, these two extra costs must be smaller than the savings in transhipment costs. 
Equation 1: The sea-river equation.

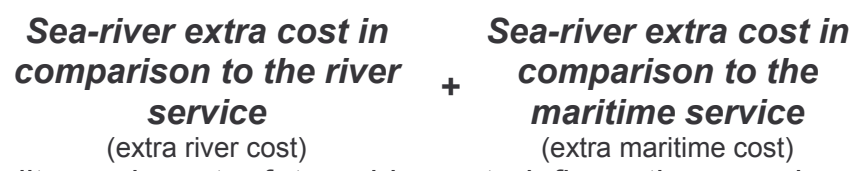

\author{
Saving costs in \\ transhipment \\ (handling cost, port dues, cost \\ of time spent in port)
}

The quality and cost of transhipment defines the sea-river shipping's competitiveness. The more the handling is expensive and/or of bad quality, the more attractive the sea-river transport option becomes. Consequently, this transport solution is more efficient when the handling is complex and/or costly. On the contrary, it is less efficient when the stevedoring is competitive.

When the sea-river transport is more efficient than "river + sea" service, advantages derived are analogous to the "absolute cost advantages" defined by Bain (1956). According to him, absolute cost advantages reflect costs in production or distribution that differ between established firms and entrants, independently of the scale of output. At any comparable scale of operations, the costs for the established firms would be at a lower level than for the potential entrants: "...if the prospective unit costs of production of potential entrant firms are generally, and more or less at any common scale of operations, higher than those of established firms..." (Bain 1956, p. 44). Using a graph to depict this relationship, the long-run average cost curve of the entrant would then lie at a higher level than that of an established firm. In order to explain such continuous differences in terms of unit prices, he identifies two root causes. Either, the entrant must use inferior production techniques compared with the ones of the established firm and/or he pays higher prices for the productive factors.

Suppose that we have two operators in competition: on the one hand a sea-river operator and on the other hand a "river + sea" carrier. If the sea-river equation is established, sea-river has a cost advantage. This benefit recalls the Bain absolute cost advantage theory. Under certain conditions, at any comparable scale of operations (transported tonnage); the sea-river alternative has lower costs than the "river + sea" option. The "river + sea" carrier uses "second-rate" transport techniques. On the one hand, we have two transport units plus one transhipment, while on the other hand only one ship sails both inland and coastal waters. The different technologies used to carry freight can be compared to the different production techniques in Bain's theory. We have neither established firms nor potential entrants. 


\section{TRANSPORT TECHNOLOGIES AND PRODUCTION COSTS.}

To determine the tipping point between the two transport alternatives, we must compare sea-river and "river + sea" production functions. The inland waterways network limits the size of sea-river transport units. Water draught, bridge/tunnel clearance and the length and width of locks define the maximum transport unit size. As we can see below (Figure 2), the total cost function is discontinuous. For any given journey, the sea-river total cost is rising with the transported tonnage. Each line represents one ship's total transport costs. Contrary to maritime transport, a sea-river ship cannot be enlarged to carry more freight. The number of ships required is a monotonically increasing function of the tonnage to be transported. When a vessel is fully loaded, the operator has to use another ship in order to increase the capacity further.

Figure 2: Sea-river total cost function departing from a Rhône-Saône river port.

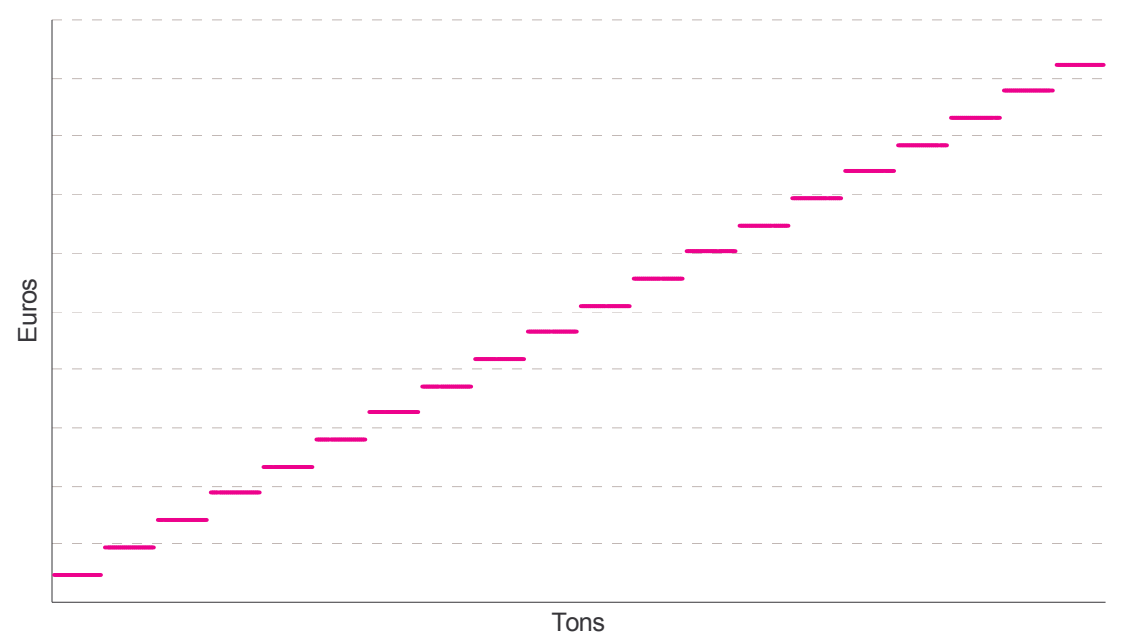

Up to the capacity of a single sea-river vessel, we have economies of scale (Figure 3). The sea-river cost per ton is decreasing. The cost of carrying one additional ton is lower than the cost of the previous ton. For any given journey departing from the Rhône-Saône basin, when the transported tonnage increases the total sea-river cost per ton tends to be constant.

Figure 3: Sea-river total cost per ton function departing from a Rhône-Saône river port.

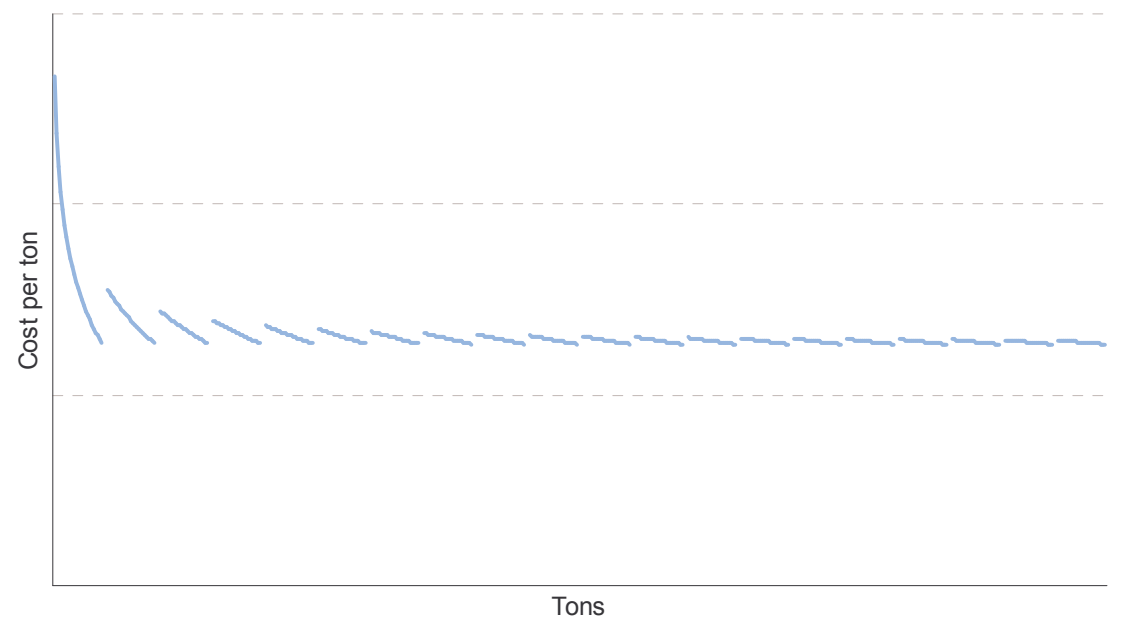

In order to make the cost function continuous, we assume without loss of generality that one shipment corresponds to one transport unit (river and sea-river ships). Thus each transported cargo requires one transport unit. The highest cargoes size is limited by the transport unit's technical specifications (weight limits, hold volume...). We differentiate three kinds of cargo: dry bulk (cereals, minerals...), container and heavy goods. We limit the study to the dry bulk and container transport markets. Thus, we determine the cargo size, in terms of tonnage, that divides the transport market. 


\subsection{Sea-river production function, average and marginal costs:}

The Sea-river cost function consists of two components: one refers to the river transport segment while the second refers to the maritime leg.

Equation 2: Total sea-river shipping cost: $T C_{S R}\left(b c_{t, d}\right)=\left(A_{R}+B_{M}\right) \times b c_{t, d}$

- $\quad b c_{t, d}$ indicates the number of cargo(es) to be transported - $b c_{t, d}$ for bulk cargo(es). It depends on $t$ the total tonnage to be transported and $d$ the product density. Owing to the assumption that one cargo corresponds to one ship; this number is equivalent to the number of sea-river vessel(s) required to transport these cargo(es).

$b c_{t, d}=\frac{t}{\overline{b c_{S R}}(t, d)} ; \overline{b c_{S R}}(t, d)$ represents the greatest cargo (size) that can be loaded according to the sea-river ship's hold features and weight capacity. For $\left.\left.t>0 ; \overline{b c_{S R}} \in\right] 0 ; \bar{t}_{S R}\right]$ ranges between 0 and $\bar{t}_{S R}$ : one sea-river vessel's highest carrying capacity (in terms of tons). The $\overline{b c_{S R}}(t, d)$ value depends on two components: the ship technical characteristics (weights limits, hold volume) and on the kind of transported dry bulk (tons: $t$ and density: d). $b c_{t, d} \in \llbracket 1 ;+\infty \llbracket$ is a whole number ranging between 1 and infinity.

- $A_{R}$ is the river component. It expresses the cost of river transport for one sea-river transport unit. It embodies the cost of time spent in the river port and hauling cost for the river distance $D_{R}$. The time spent in the river port depends on the handling capacities (in tons loaded/unloaded per day) of this port.

- $\quad B_{M}$ is the maritime component, expressing the sea-river costs at sea for one transport unit. It includes: the port dues, the cost of time spent in the maritime port and hauling cost at sea (for the maritime distance $D_{M}$ ). The time spent in the seaport depends on the handling capacities (in ton loaded/unloaded per day). We suppose that the handling capacities in both ports (river and maritime) are similar.

- $D$ stays for the total distance travelled as the sum of the river distance and the maritime distance: $D=D_{R}+D_{M}$

The sea-river average cost is the cost per cargo transported. The marginal cost (MC) function is expressed as the derivative of the total cost (TC) function with respect to quantity - here the number of transported cargo(es).

\section{Equation 3: Sea-river average cost:}

$A C_{S R}\left(b c_{t, d}\right)=\frac{T C_{S R}\left(b c_{t, d}\right)}{b c_{t, d}}=\frac{\left(A_{R}+B_{M}\right) \times b c_{t, d}}{b c_{t, d}}=\left(A_{R}+B_{M}\right)$

for $\mathrm{t}>0: b c_{t, d} \in \llbracket 1 ;+\infty \llbracket$

The sea-river average cost is a constant. For any given journey, transporting either many (similar) cargoes or only one, the cost per ton is the same.

\section{Equation 4: Sea-river marginal cost:}

$M C_{S R}\left(b c_{t, d}\right)=\frac{\partial T C_{S R}\left(b c_{t, d}\right)}{\partial b c_{t, d}}=\left(A_{R}+B_{M}\right)$

$M C_{S R}\left(b c_{t, d}\right)=\left(A_{R}+B_{M}\right)$

Average costs and marginal costs are constant and equal. This reveals constant returns to scale. The marginal cost of transporting an additional cargo is the cost of the additional sea-river vessel needed to carry that cargo. To double the output, here the number of transported cargoes requires doubling the input; that is the number of transport units. Transporting one additional cargo costs the same as the previous cargo. 


\section{2 "River + sea" production function, average and marginal costs:}

The "River + sea" service cost function includes three separate cost functions: the river transport cost, the transhipment cost and the maritime cost. The 'on river' and 'at sea' transport units are different. Thus we have two different cost functions, with different returns to scale.

\section{2.a River production function, average and marginal costs:}

Barges and push convoys must abide by navigational restrictions on rivers and canals (water draught, freeboard, length and width of locks). Thus, transport unit size is restricted. As a result, river and sea-river cost functions are closed. For a given river journey, the river total cost rises with the transported tonnage. River ships cannot be enlarged to carry more freight. Consequently, the number of ships used is increasing with the transported tonnage. When a river vessel is fully loaded, the operator has to use another one. Up to the river vessel's highest weight capacity, the river cost per ton is decreasing. These characteristics are the same as the sea-river cost function.

Equation 5: Total river cost: $T C_{R}\left(b c_{t, d}\right)=E_{R} \times b c_{t, d}$

- $b c_{t, d}$ indicates the number of cargo(es) to be transported by the river service. It depends on $t$ the total tonnage to be transported and $d$ the product density. Owing to the assumption that one cargo corresponds to one ship: this number is equivalent to the number of river vessel(s) required to transport these cargo(es).

$b c_{t, d}=\frac{t}{\overline{b c_{R}}(t, d)} ; \overline{b c_{R}}(t, d)$ represents the highest cargo (size) that can be loaded according to the river ship's hold features and weight capacity. For $\left.\left.t>0 ; \overline{b c_{R}} \in\right] 0 ; \bar{t}_{R}\right]$ ranges between 0 and $\bar{t}_{R}$ : one river vessel's greatest carrying capacity (in terms of tons). The $\overline{b c_{R}}(t, d)$ value depends on two components: the ship's technical characteristics (weights limits, hold volume) and on the kind of dry bulk transported (tons: $t$ and density: $d$ ). $b c_{t, d} \in \llbracket 1 ;+\infty \llbracket$ is a whole number ranging between 1 and infinity.

- $\quad E_{R}$ expresses, for one transport unit, the river transport cost (haulage and handling). It embodies the port dues, the cost of the time spent in the river port and in the maritime port (for the transhipment) as well as the hauling cost proportional to the river distance $D_{R}$. The time spent in the two ports depends on their handling capacities (in ton loaded/unloaded per day), which are supposed to be equal.

The river average cost is the cost per transported cargo on the river leg.

\section{Equation 6: River average cost:}

$A C_{R}\left(b c_{t, d}\right)=\frac{T C_{R}\left(b c_{t, d}\right)}{b c_{t, d}}=\frac{E_{R} \times b c_{t, d}}{b c_{t, d}}=E_{R}$

for $\mathrm{t}>0: b c_{t, d} \in \llbracket 1 ;+\infty \llbracket$

Equation 7: River marginal cost:

$M C_{R}\left(b c_{t, d}\right)=\frac{\partial T C_{R}\left(b c_{t, d}\right)}{\partial b c_{t, d}}=E_{R}$

$M C_{R}\left(b c_{t, d}\right)=E_{R}$

The river cost function characteristics are similar to the sea-river shipping ones. Average and marginal costs are constant and equal. Therefore, the two transport technologies have constant returns to scale. 


\section{2.b Handling production function, average and marginal costs:}

The handling costs relate to the transhipment of cargo(es) between river and maritime transport units. The handling cost is increasing with the number of transported cargoes.

Equation 8: Total handling cost: $T C_{H}\left(b c_{t, d}\right)=G_{H} \times b c_{t, d}$

- $b c_{t, d}$ indicates the number of cargo(es) to be transported by the river service. It is the number of cargoes to be transhipped between river and maritime vessels or vice-versa.

- $G_{H}$ is the handling cost per cargo in transhipment port.

The handling cost is growing with $b c_{t, d}$, the transported cargo(es).

Equation 9: Handling average cost: $A C_{H}\left(b c_{t, d}\right)=\frac{T C_{H}\left(b c_{t, d}\right)}{b c_{t, d}}=G_{H}$

The average cost, is the transhipment cost per cargo, while the marginal handling cost is the cost to tranship one additional cargo.

Equation 10: Handling marginal cost: $M C_{H}\left(b c_{t, d}\right)=\frac{\partial T C_{H}}{\partial b c_{t, d}}=G_{H}$

Average costs and marginal costs are constant and equal. The handling costs in the transhipment port have constant returns to scale. Handling one additional cargo costs the same as the previous one.

\section{2.c Maritime production function, average and marginal costs:}

In contrast with the inland network, sea transport is much less restricted. Ship size is not usually limited by infrastructure. Therefore ship-owners can use larger ships in order to obtain the lowest total cost per cargo ton. It follows that an optimal ship size may exist. The subject of optimal ship size has been widely investigated by scholars. Such works are those of Thoburn (1960), McKinsey and Co. Inc. (1967), Benford (1968), Heaver (1968), Erichsen (1971), Goss and Jones (1971), Goss (1974), Ryder and Chapell (1979), Talley (1990), Gilman (1980, 1983, 1999), Pearson (1988), McLellan (1997), Lim (1994), Cullinane and Khanna (1999, 2000), Stopford (2002). According to Jansson and Schneerson $(1982,1987)$, the optimal ship size is determined by minimising costs per ton at sea and costs per ton in port. It is argued that costs per ton at sea decrease with the ship size, while the ones per ton in port increase, due to the cost of time spent in ports. The optimal ship size is obtained by trading off economies of scale in hauling operations with diseconomies of scale in handling operations. Diagrammatically, their model is given in Fig. 4.

Figure 4: Optimal ship size.

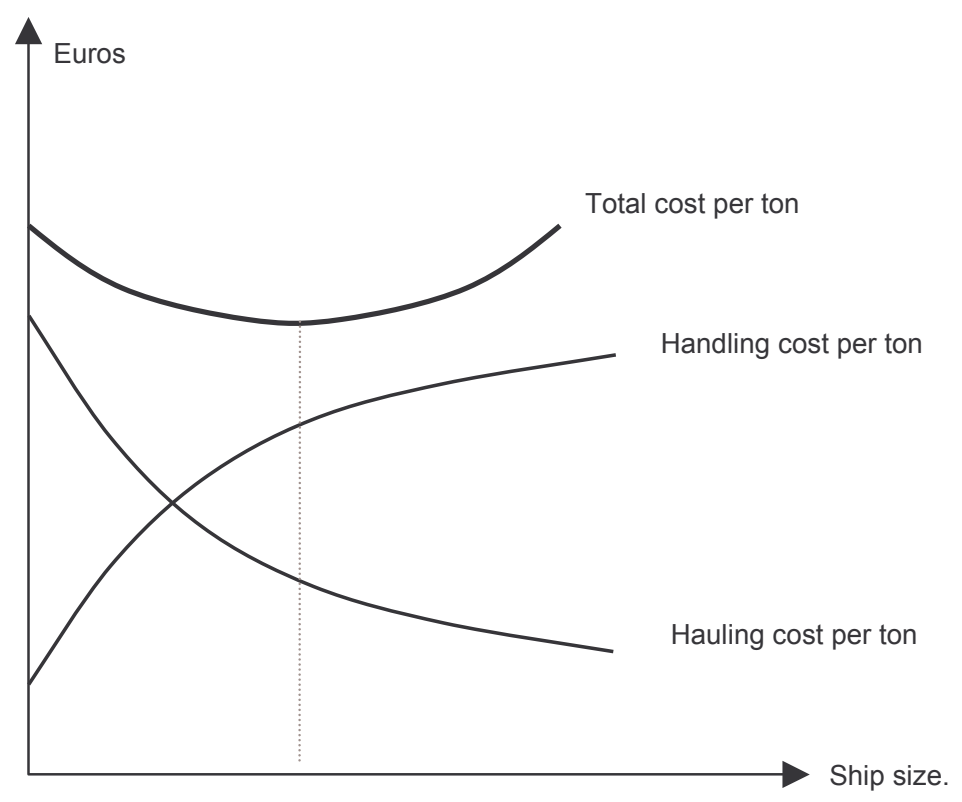


The optimum ship size is found at the point where the slopes of the hauling cost curve and the handling cost curve have the same absolute value. Jansson and Shneerson (1982) give an example: the optimum size of a coal carrier. The optimum ship size equation yields a 240,000-dwt vessel.

The average bulk carrier's size has crept steadily upwards, increasing by $60 \%$ between 1975 and 2002, an average rate of $2.2 \%$ per annum. Today the standard Capesize bulker (the biggest vessel) is $175,000 \mathrm{dwt}$ compared with 120,000 dwt 20 years ago; a 46\% increase. Until recently the containership fleet followed a very similar pattern to bulk carriers. Stopford (2002) estimates the container fleet's economies of scale. His estimate confirms the tendency for returns to diminish. Increasing ship size from 1,000 TEU to 2,000 TEU saves $20 \%$ in the unit cost of transport; from 2,000 to 4,000 TEU saves 7\%; and from 4,000 to 6,000 TEU saves only $4 \%$. Beyond $8,000 \mathrm{TEU}$, the economies of scale are hard to detect. Economies of scale diminish beyond 3,000 TEU and over 8,000 TEU the savings become immeasurably small. Cullinane and Khanna (2000) advance the same argument. Their results suggest that economies of ship size are enjoyed until about 8,000 TEU. The diseconomies of ship size in port outweigh economies of size at sea at greater TEU.

These conclusions have to be re-evaluated. In its annual review 2006, BRS ${ }^{2}$ refers to the $20 \%$ growth per annum over the next three years of the containership fleet above 4000 TEU, while the increase for ships less than 4000 TEU is only $9 \%$ for the same period. The trend is for bigger size of container ships to reduce costs by economy of scales (Drewry Shipping Consultants, 1996; Wijnolst et al., 1999; Tozer and Penfold, 2000; Tozer, 2003). Germanisher Lloyd has developed a design for a 9300 TEU containership. Bureau Veritas has produced design plans for a 12500 TEU vessel. Lloyd's Register has also investigated the possibility of 12500 TEU ship, creating a new container ship generation: the "ultra large container ship" (ULCS) (Tozer and Penfold, 2001). Until recently, the 10000 TEU mark was considered as a significant psychological milestone. That changed when China Ocean Shipping Corporation (COSCO), in January 2005, was the first shipping line in the world to order containerships with over 10000 TEU capacity. The vessels will be delivered between late 2007 and mid 2008. A major design and feasibility study is underway at Delft University of Technology on the next generation of containership that will carry 18000 containers. The ULCS do not only surpass all past container ship generations in terms of size, but also in terms of technical sophistication, design and speed. These technical improvements permit the maximum ship size to be increased, in order to obtain the lowest total cost per cargo ton. Maersk took delivery of the M/S Emma Maersk on 1st September 2006 built by Odense Steel Shipyard in Denmark. The Emma Maersk is the first in a new series of PS-class vessels. This transport unit set new standards for global shipping, creating new economies of scale. Measuring $397 \mathrm{~m}$ long and $56 \mathrm{~m}$ wide, the Emma Maersk is the world's largest container vessel and is able to carry 13500 TEU.

Sea-river shipping is optimal at a smaller scale. The transported tonnage and cargoes are below optimal maritime ship size: about 2,000 to $2,500 \mathrm{dwt}$ or 90 to $100 \mathrm{TEU}$. Consequently we can consider that the maritime fleet, which is in competition with sea-river vessels at sea, enjoys economies of scale. Indeed, on the maritime leg, these vessels are significantly smaller than the optimal ship size defined by transport economics. Therefore, on the maritime leg and for sufficiently long distances, economies of scale in hauling operations easily outweigh diseconomies of scale in handling operations. Total cost per ton decreases with the ship size.

In order to define hauling costs at sea, we take up the daily capital cost function defined by Cullinane and Khanna (2000). This is dependent on ship size, thus economies of scale in construction are realised. Hence, the size elasticity of capital cost is not ignored and the effect of economies of scale in capital cost is captured.

Equation 11: Total maritime cost: $T C_{M}\left(b c_{t, d}\right)=L_{M} k x_{b c}^{e}$

$x_{b c}$ is the ship size in TEU or dwt to carry the cargo(es) $b c_{t, d} \cdot x_{b c}$ depends on $b c_{t, d}$ the number of cargo(es) to be carried by "river + maritime" service on the river transport segment. On the maritime leg, when the number of cargoes to be transported increases, "river + sea" operators can use a larger ship. Up to the optimum defined above, if $b c_{t, d}$ required two river units, instead of using two maritime ships, ship-owners can exploit one larger ship.

- $\quad e$ expresses the ship size elasticity of capital costs.

- $\quad L_{M}$ indicates the number of days required to carry the cargo $b c_{t, d}$ between the transhipment port and the arrival/departure port (in which the merchandise is unloaded/loaded). This parameter includes the time spent in the two ports (transhipment port and arrival/departure seaport) and days at sea and the port dues in both ports.

- $\quad k$ is the ship cost per day. $k$ depends on $x_{b c}$ the ship size.

${ }^{2}$ Barry Rogliano Salles shipbrokers, website http://www.brs-paris.com/index.php 
Capital costs were estimated by regressing the construction costs against the ship size. The estimated value of the ship size elasticity of capital costs has been calculated in many studies (see Table 1).

Table 1: Ship size elasticities of capital cost.

\begin{tabular}{|c|c|c|c|}
\hline Ship type & $\begin{array}{l}\text { Capital } \\
\text { cost }\end{array}$ & $\begin{array}{l}\text { Operating cost } \\
\text { (except fuel) }\end{array}$ & $\begin{array}{l}\text { Fuel cost } \\
\text { (for propulsion) }\end{array}$ \\
\hline $\begin{array}{l}\text { Tramps } \\
\text { (Thoburn, 1960) } \\
\text { Liner }\end{array}$ & 0.67 & 0.4 & 1.00 \\
\hline $\begin{array}{l}\text { (Getz et al., 1967) } \\
\text { Dry bulk carrier }\end{array}$ & 0.6 & 0.6 & - \\
\hline $\begin{array}{l}\text { (Goss and Jones, 1971) } \\
\text { Tanker }\end{array}$ & 0.7 & 0.4 & 0.8 \\
\hline $\begin{array}{l}\text { (Heaver, 1968) } \\
\text { Jansson and Schneerson } \\
\quad \text { estimate }\end{array}$ & 0.6 & 0.3 & 0.6 \\
\hline (Regression results) & 0.6 & 0.4 & 0.72 \\
\hline
\end{tabular}

$0<e<1$ indicates that capital costs increase less quickly than ship size.

Table 2: Representative newbuilding prices in selected years (millions of dollars).

\begin{tabular}{lccccccccc}
\hline & 1980 & 1985 & 1990 & 1995 & 2000 & 2001 & 2002 & 2003 & 2004 \\
\hline 30-50 000 dwt bulk carrier & 17 & 11 & 24 & 25 & 20 & 18 & 15 & 22 & 30 \\
70-74 000 dwt bulk carrier & 24 & 14 & 32 & 29 & 23 & 20 & 20 & 25 & 35 \\
120 000 dwt bulk carrier & 32 & 27 & 45 & 40 & 40 & 34 & 31 & 47 & 61 \\
\hline
\end{tabular}

Table 2 illustrates the characteristic of $e$. Upgrading from a bulk carrier of 50,000 dwt to another of $120,000 \mathrm{dwt}$ doubles the capital costs, while the transport capacity is more than doubled. 


\section{Equation 12: Maritime average cost or Cost per cargo at sea:}

$$
\begin{aligned}
& A C_{M}\left(b c_{t, d}\right)=\frac{T C_{M}}{b c_{t, d}}=\frac{L_{M} k x_{b c}^{e}}{b c_{t, d}}=L_{M} k x_{b c}^{(e-1)} \\
& A C_{M}\left(b c_{t, d}\right)=L_{M} k x_{b c}^{(e-1)} \\
& 0<e<1, L \text { and } k>0 \\
& x_{b c}^{(e-1)}>0, \forall t>0 \\
& \Leftrightarrow A C_{M}>0, \forall t>0
\end{aligned}
$$

Equation 13: Maritime marginal cost or Marginal cost at sea:

$$
\begin{aligned}
& M C_{M}=\frac{\partial T C_{M}}{\partial b c_{t, d}}=e L_{M} k x_{b c}^{(e-1)} \\
& 0<e<1, L_{M} \text { and } k>0 \\
& x_{b c}^{(e-1)}>0, \forall t>0 \\
& \Leftrightarrow M C_{M}>0, \forall t>0 \\
& \frac{\partial^{2} C_{M}}{\partial b c_{t, d}^{2}}=(e-1) e L_{M} x_{b c}^{(e-2)} \\
& (e-1)<0 \text { and } x_{b c}^{(e-2)}>0, \forall t>0 \\
& \Leftrightarrow \frac{\partial^{2} C_{M}}{\partial b c_{t, d}{ }^{2}}<0
\end{aligned}
$$

Average and marginal costs depend on $x_{b c}^{(e-1)}$. The limits of $x_{b c}^{(e-1)}$ between 0 and infinity are as follows:

$\lim _{t \rightarrow 0^{+}} x_{b c}{ }^{(e-1)}=+\infty$ and $\lim _{t \rightarrow+\infty} x_{b c}^{(e-1)}=0^{+}$

For each ship whose size is lower than the optimal one defined by transport economists, the maritime average and marginal costs are positive and decreasing. Up to the optimum defined above, the cost function takes account of economies of scale. The cost per cargo at sea decreases with ship size or cargo volume. The cost of producing one additional unit is less than the cost incurred in producing the previous unit. That is, the cost of carrying one additional cargo is less than the cost of the previous one. 


\section{2.d "River + maritime" production function, average and marginal costs:}

A "River + sea" service cost function contains three separate cost functions: the river transport cost, the maritime cost and the transhipment cost. What happens to the "river + maritime" average and marginal costs?

The "river + sea" cost function is:

Equation 14: Total "river + sea" service cost:

$$
\begin{aligned}
& T C_{R+S}\left(b c_{t, d}\right)=T C_{R}+T C_{H}+T C_{M} \\
& T C_{R+S}\left(b c_{t, d}\right)=D_{R} \times b c_{t, d}+G_{H} \times b c_{t, d}+L_{M} k x_{b c}^{e}
\end{aligned}
$$

Just like the "river + sea" alternative total cost, the "river + sea" average cost is the addition of three average costs, ibid. for the marginal cost.

Equation 15: "River + sea" service average cost:

$$
A C_{R+S}\left(b c_{t, d}\right)=A C_{R}+A C_{H}+A C_{M}
$$

$$
A C_{R+S}\left(b c_{t, d}\right)=E_{R}+G_{H}+L_{M} k x_{b c}^{(e-1)}
$$

Equation 16: "River + sea" service marginal cost:

$$
M C_{R+S}\left(b c_{t, d}\right)=M C_{R}+M C_{H}+M C_{M}
$$

$$
M C_{R+S}\left(b c_{t, d}\right)=E_{R}+G_{H}+e L_{M} k x_{b c}^{(e-1)}
$$

$0<e<1$

$E, G, L$ and $k>0$

Average and marginal costs depend on $x_{b c}^{(e-1)}$. We have seen that $x_{b c}^{(e-1)}$ is positive and decreasing with ship size or $b c_{t, d}$ (the number of cargo(es) to be transported). Because, $x_{b c}^{(e-1)}$ has an asymptote at zero, "river + sea " average/marginal cost tends to the sum of river average/marginal cost $\left(A C_{R}=M C_{R}=E_{R}\right)$ and handling average/marginal cost $\left(A C_{H}=M C_{H}=G_{H}\right)$.

\section{Equation 17: “River + sea” service average cost:}

$A C_{R+S}\left(b c_{t, d}\right)=E_{R}+G_{H}+L_{M} k x_{b c}^{(e-1)}$

For each ship whose size is smaller than the optimum defined previously $L_{M} k x_{b c}^{(e-1)}$ tends to zero when ship size or the number of transported cargo increases.

$\Leftrightarrow \lim _{t \rightarrow+\infty} A C_{R+S}\left(b c_{t, d}\right)=E_{R}+G_{H}$

Equation 18: "River + sea” service marginal cost:

$$
M C_{R+S}\left(b c_{t, d}\right)=E_{R}+G_{H}+e L_{M} k x_{b c}^{(e-1)}
$$

For each ship whose size is smaller than the optimum defined previously $e L_{M} k x_{b c}^{(e-1)}$ tends to zero when ship size or number of transported cargo increases.

$\Leftrightarrow \lim _{t \rightarrow+\infty} M C_{R+S}\left(b c_{t, d}\right)=E_{R}+G_{H}$ 
Diagrammatically we have these functions:

Figure 5 : “River + sea” average cost function.

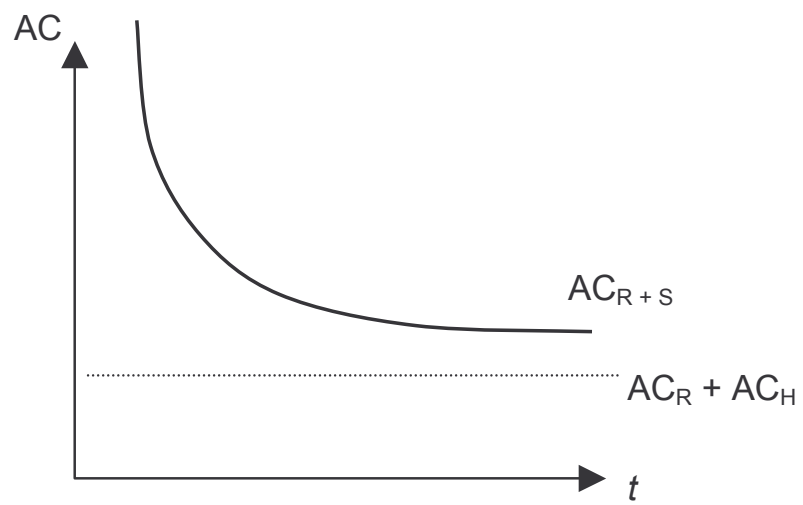

Figure 6 : "River + sea” marginal cost function.

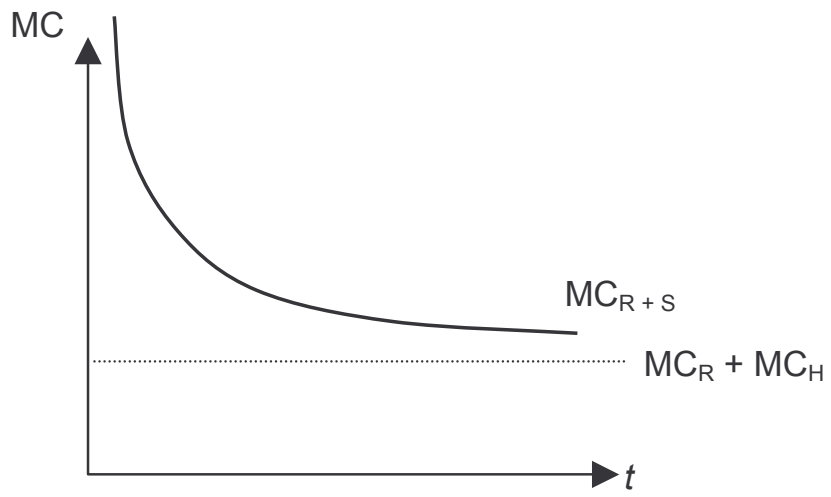

The "River + sea" cost function takes account of the economies of scale. If the number of cargoes to be transported increases, the marginal cost tends to the sum of river and handling marginal costs. 


\section{SHARE OF THE MARKET AND TIPPING POINT BETWEEN SEA-RIVER TRANSPORT AND "RIVER+SEA" SERVICE}

A transport chain (sea-river shipping or "river + sea" service) is attractive if it can ensure lower costs than its competitors. The goal of firms is to set the production level $(q)$ such that profits $(\pi)$ are maximized, where $\pi(q)=T R-T C=p(q) q-C(q)$

$T R$ total revenue is the total amount of money the firm collects in sales.

$T C$ total cost means the cost of all factors of production.

A firm's profit is defined as its total revenues minus its total costs.

Economic theory has defined the MR=MC rule (MR: Marginal Revenue; MC: Marginal Cost) to maximize profit. A firm should increase its output as long as the marginal revenue earned from the production of additional units is greater than the marginal cost of those units. Marginal revenue is the additional benefit from selling one more unit of product. Marginal cost is the additional cost incurred in producing one more unit of output. Therefore, firms use MR and MC to decide how much to produce.

- Suppose increasing output by one unit will bring in more additional revenues than it costs to produce, i.e. $M R>M C$, then it makes sense to produce the unit. Doing so will create more additional revenues than additional costs.

- On the other hand, suppose the last unit costs more to produce than it benefits. Then MR<MC. It makes sense to cut back the production (not produce that unit after all), because the last unit creates more added cost than added benefit.

- So the point at which the efficiency is established is where MR=MC. This is the general profit maximisation rule.

The firm will maximize profits or minimise losses by producing at the MR=MC level.

In our case, each firm stops producing when its marginal cost equals its competitor's marginal cost. Every operator (sea-river or "river + sea") looks for the maximum output (here transported cargo), which results in a production cost no more than that of its competitor. Therefore the intersection of the marginal cost curves determines the market share between sea-river and "river + sea" operators. That is: at what threshold, in terms of tonnage, sea-river vessels are more efficient than "barge+shortsea" transport service.

Equation 19: Sea-river shipping and "river + sea" service: share of the market.

$$
\begin{aligned}
& M C_{S R}=M C_{R+S} \\
& A_{R}+B_{M}=E_{R}+G_{H}+e L_{M} k x_{b c}^{(e-1)} \\
& \Leftrightarrow\left(A_{R}+B_{M}\right)=\left(E_{R}+G_{H}\right)+e L_{M} k x_{b c}^{(e-1)} \\
& \Leftrightarrow \frac{\left(A_{R}+B_{M}\right)-\left(E_{R}+G_{H}\right)}{e L_{M} k}=x_{b c}^{(e-1)} \\
& \Leftrightarrow\left[\frac{\left(A_{R}+B_{M}\right)-\left(E_{R}+G_{M}\right)}{e L_{M} k}\right]^{\frac{1}{e-1}}=x_{b c}^{*}
\end{aligned}
$$

$x_{b c}^{*}$ is the tipping point. That is, the ship size in terms of TEU or dwt which splits the market between sea-river shipping and "river + sea" service. $x_{b c}^{*}$ depends on $b c_{t, d}$.

As we can see below, the maritime offer is very diversified (Table 3). This table depicts the arrivals (inwards only) of dry bulk vessels calling at main European Union (15 EU countries pre 2004) ports (ports handling over 1 million tons per year), in 2004. We find many different ship sizes. Consequently, we can reason either with ship size or tonnage. 
Table 3: Dry bulk vessel traffic by size of vessel (in number of vessels).

\begin{tabular}{|c|c|}
\hline ship size (in terms of tons) & number of vessels \\
\hline Less than 100 & 69 \\
\hline From 100 to less than 500 & 3564 \\
\hline From 500 to less than 1000 & 1736 \\
\hline From 1000 to less than 2000 & 7261 \\
\hline From 2000 to less than 3000 & 5367 \\
\hline From 3000 to less than 4000 & 3694 \\
\hline From 4000 to less than 5000 & 1588 \\
\hline From 5000 to less than 6000 & 1083 \\
\hline From 6000 to less than 7000 & 617 \\
\hline From 7000 to less than 8000 & 626 \\
\hline From 8000 to less than 9000 & 342 \\
\hline From 9000 to less than 10000 & 400 \\
\hline From 10000 to less than 20000 & 4029 \\
\hline From 20000 to less than 30000 & 2526 \\
\hline From 30000 to less than 40000 & 2492 \\
\hline From 40000 to less than 50000 & 734 \\
\hline From 50000 to less than 80000 & 664 \\
\hline From 80000 to less than 100000 & 829 \\
\hline From 100000 to less than 150000 & 115 \\
\hline From 150000 to less than 200000 & 51 \\
\hline From 200000 to less than 250000 & 1 \\
\hline From 250000 to less than 300000 & 0 \\
\hline More than 300000 & 2 \\
\hline Unknown & 77 \\
\hline Total & 37867 \\
\hline
\end{tabular}

Whatever the cargo (to be transported) weight, that divides the market, there is always a ship of that size. Therefore we can substitute the ship size $\left(x_{b c}^{*}\right)$ by tons. Then we can write:

$$
\left[\frac{\left(A_{R}+B_{M}\right)-\left(E_{R}+G_{M}\right)}{e L_{M} k}\right]^{\frac{1}{e-1}}=t^{*}
$$

The tipping point depends on the two marginal cost curves. Diagrammatically we have:

Figure 7 : The market share between the sea-river transport and the "river + sea" solution.

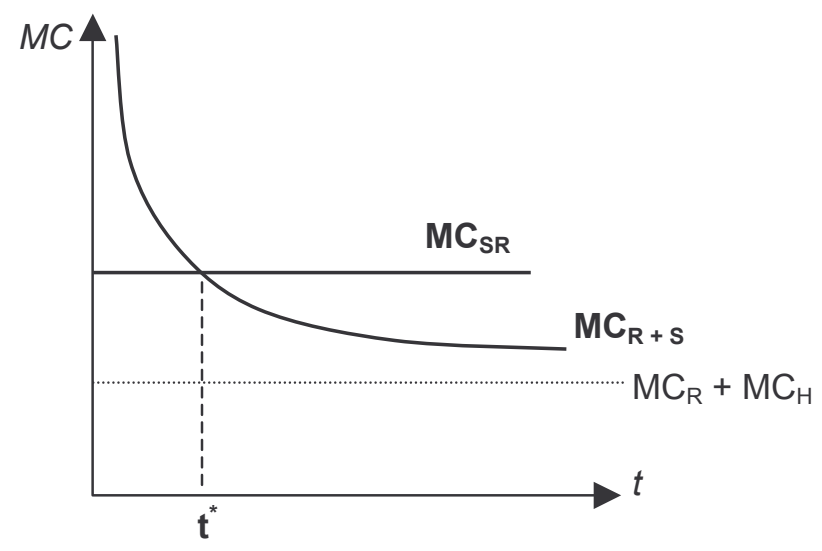

Up to $t^{*}$ the sea-river service is more efficient, above this point "river + sea" transport is economically more attractive. Up to $t^{*}$ sea-river shipping has a partial cost advantage. At any comparable scale of operations, sea-river costs will be at a lower level than the "river + sea" ones; conversely, from $t$. Each transport chain has a partial cost advantage with respect to the other. Sea-river shipping is efficient for small cargoes, while "river + sea" transport is more attractive for greater cargoes. 
What happens if the sea-river shipping marginal cost tends to the sum of river and handling marginal costs?

$\left[\frac{\left(A_{R}+B_{M}\right)-\left(E_{R}+G_{H}\right)}{e L_{M} k}\right]^{\frac{1}{e-1}}=t^{*}$

Calculation of $t^{*}$ when $\left(A_{R}+B_{M}\right)$ tends to $\left(E_{R}+G_{H}\right)$ :

$0<e<1 \Leftrightarrow \frac{1}{e-1}<0$

$\lim _{\left(A_{R}+B_{M}\right) \rightarrow\left(E_{R}+G_{H}\right)}\left(A_{R}+B_{M}\right)-\left(E_{R}+G_{H}\right)=0$

$\lim _{\left(A_{R}+B_{M}\right) \rightarrow\left(E_{R}+G_{H}\right)} \frac{\left(A_{R}+B_{M}\right)-\left(E_{R}+G_{H}\right)}{e L_{M} k}=0$

We write: $X=\frac{\left(A_{R}+B_{M}\right)-\left(E_{R}+G_{H}\right)}{e L_{H} k}$

$X^{\left(\frac{1}{e-1}\right)}=\frac{1}{X^{\left(\frac{1}{1-e}\right)}}$

$\lim _{X \rightarrow 0^{+}} X^{\left(\frac{1}{1-e}\right)}=0^{+}$

$\lim _{X \rightarrow 0^{+}} \frac{1}{X^{\left(\frac{1}{1-e}\right)}}=+\infty$

$\lim _{\left(A_{R}+B_{M}\right) \rightarrow\left(E_{R}+G_{H}\right)}\left[\frac{\left(A_{R}+B_{M}\right)-\left(D_{R}+G_{H}\right)}{e L_{M} k}\right]^{\frac{1}{e-1}}=\lim _{\left(A_{R}+B_{M}\right) \rightarrow\left(E_{R}+G_{H}\right)} t^{*}=+\infty$

The closer $\left(A_{R}+B_{M}\right)$ is to $\left(E_{R}+G_{H}\right)$, the larger $t^{*}$ is. $t^{*}$ moves to the right. The efficiency of sea-river shipping will increase.

- If $\left(A_{R}+B_{M}\right)=\left(E_{R}+G_{H}\right)$ : the sea-river shipping marginal cost curve and the asymptote of the "river + sea" transport marginal cost curve form the same curve. The tipping point between the two transport solutions is undetermined. At any tonnage, sea-river shipping costs are lower than the "river + sea" service ones.

- If $\left(A_{R}+B_{M}\right)>\left(E_{R}+G_{H}\right)$ : the market share will depend on the difference between $\left(A_{R}+B_{M}\right)$ and $\left(E_{R}+G_{H}\right)$. The greater this difference is, the smaller the tipping point is. $t^{*}$ moves to the left. The efficiency of sea-river transport decreases.

- If $\left(A_{R}+B_{M}\right)<\left(E_{R}+G_{H}\right)$ : the sea-river marginal cost curve is at a lower level than the asymptote of the "river + sea" transport marginal cost curve. The marginal cost functions do not intersect. Thus at any tonnage, the seariver solution is economically more attractive than the "river + sea" transport chain.

Some questions arise: what is the value of $x_{b c}^{*}$ or $t^{*}$ in terms of tonnage? Are sea-river shipping and "river + sea" service in competition or complementary?

It is difficult to accurately estimate the marginal cost values. However, comparing tonnage carried by sea-river transport and by the Marseille Port Authority (the transhipment port), we are able to estimate $t^{*}$. 


\section{Figure 8 :}

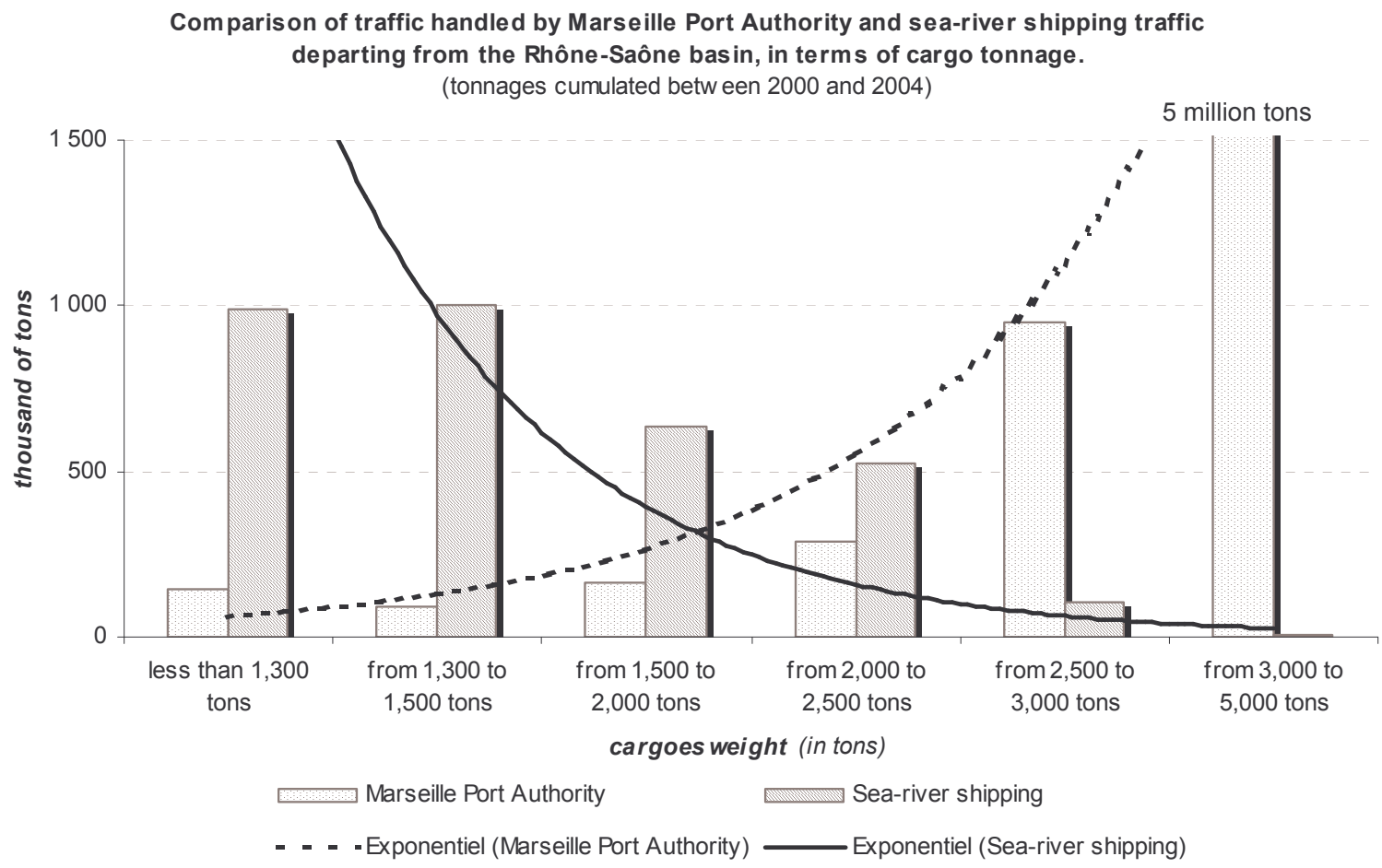

Source: C. Lopez; LET University Lyon 2, VNF dir. Inter-régionale de Lyon, Marseille Port Authority.

For small volumes, sea-river transport is more efficient. When cargoes are larger, the "river + sea" transport chain becomes more attractive. Sea-river shipping has a market niche for small cargoes. The tonnage, which divides the market, is between 1,500 and 2,000 tons. Due to restrictions on sea-river vessel size, sea-river shipping cannot transport large tonnages. Competition between the two transport chains does not arise. In its market niche, no "river + sea" operators can compete with sea-river transporters. Conversely for large cargoes, sea-river has higher costs.

Each transport chain is specialised. Sea-river shipping is particularly interesting for small Mediterranean ports that can only deal with small cargoes. "River + sea" services are left to transport large cargoes, mainly to the important Mediterranean seaports. Therefore, the transport chains are complementary. All Mediterranean ports can be served departing from the Rhône-Saône basin. Competition only exists when the transported cargo is close to $x_{b c}^{*}$ or $t^{*}$.

Our results shed light on a little-known transport mode that can contribute to developing an efficient transport policy in Europe. But, this reasoning has some limits. We suppose that some transport units (river, sea-river ship) can transport only one cargo. This hypothesis is quite strong but useful for the analysis.

After addressing the question of competition/complementarity between the two services, we try, for different ports of the Rhône-Saône corridor, to determine the geographical competitive range of sea-river shipping. 


\section{SEA-RIVER SHIPPING'S COMPETITIVE GEOGRAPHICAL MARKET AREA.}

Marcadon (1986) defines the concept of the maritime foreland. The foreland of a port is the number of other ports connected regularly (for tramping) or through shipping lines. Charlier and Fohal (2005) compare the maritime foreland of different inland seaports (Brussels, Duisburg, Liege and Paris) in years 2000-2004. The competitive navigational area of sea-river shipping is close to the concept of maritime foreland. For different ports of the Rhône-Saône corridor, we want to determine the maximum competitive distance at sea for a specific sea-river vessel.

There is a relationship between transport costs, distance and modal choice, that has been observed for a long time. We suppose that a cargo has to be transported between one river port ( $A$, that is for example Lyon) and one seaport ( $B$, that is for example Barcelona).

Figure 9: Transport costs, distance and modal choice.

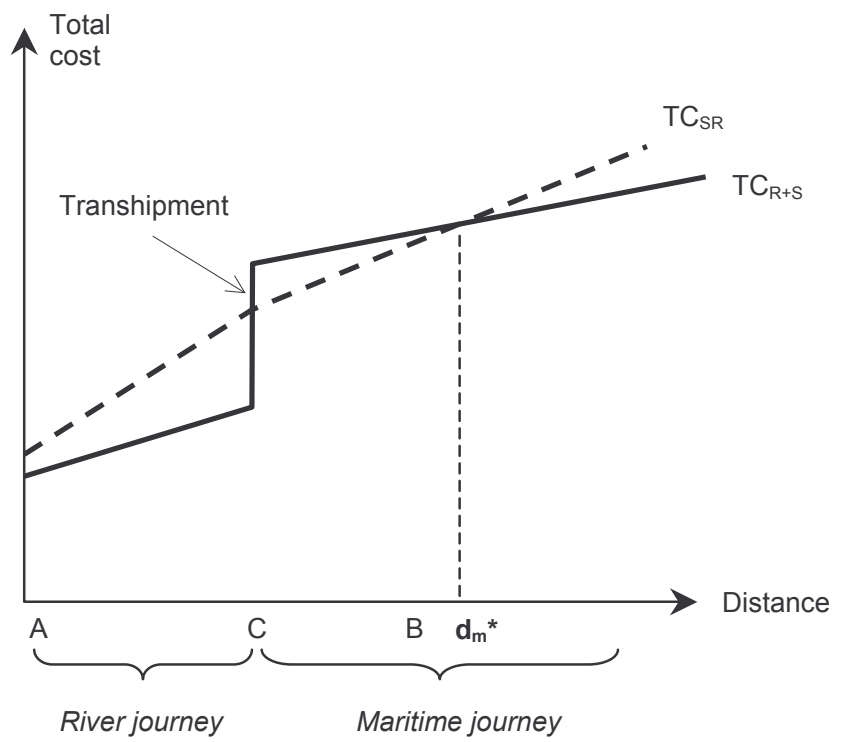

Sea-river shipping can directly connect points A (Lyon) and B (Barcelona). Seaport transhipment - point C; Marseille/Fos - is avoided. For sea-river ships, river dues are greater than maritime fees. Then, on rivers and canals, sea-river costs climb faster than costs on the maritime leg. The sea-river cost function $\left(\mathrm{TC}_{\mathrm{SR}}\right.$, dashed curve) slope changes when the ship moves to another environment (transit from river to sea or conversely).

The "river + sea" service includes three separate cost functions $\left(\mathrm{TC}_{\mathrm{R}+\mathrm{S}}\right.$, black curve): the river transport cost, the transhipment cost and the maritime cost. River and maritime costs are rising with distance. The transhipment cost in Marseille/Fos (point C) is independent of distance.

On the river segment sea-river is more expensive than river service. The handling cost (point $\mathrm{C}$ ) makes sea-river shipping viable up to $d_{m}{ }^{*}$.

At a distance $\mathbf{d}_{\mathrm{m}}{ }^{*}$, it becomes more cost-effective to use "river + sea" service than sea-river transport. For a given transported cargo and one specific sea-river ship we determine $\mathbf{d}_{\mathrm{m}}{ }^{*}$ its maximum competitive distance at sea.

Following Rissoan (1987), we define the competitive navigational area of sea-river shipping. Our specific contribution is to consider the nautical access offered by inland ports along the Rhône and the Saône. Rissoan defined this area by resolving the so called "sea-river equation" (equation 1).

Equation 1: The sea-river equation.

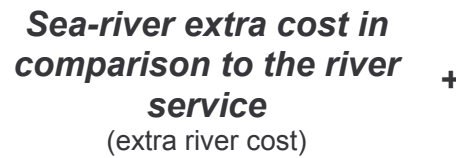

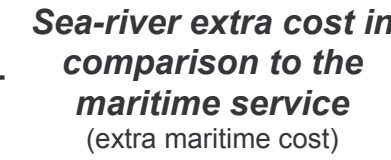

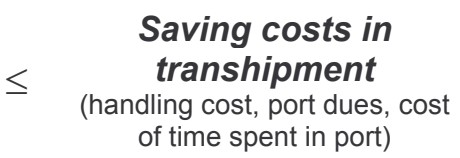

Saving costs in

ding cost, port dues, cost

The sea-river extra costs depend on the river distance $D_{R}$ (extra river cost) and the maritime distance $D_{M}$ (extra maritime cost). The savings in transhipment depend on the transported product and its characteristics (weight, density...). The two distances are unknown. Rissoan expresses the two extra costs in euros per tonkilometre. He considers one specific sea-river vessel. From its carrying capacity and the transported product 
characteristics, he deduces the saving costs. For a given cargo and a given movement, the saving is a fixed sum. Consequently, increasing the river journey obliges sea-river operators to decrease the maritime journey.

To solve his equation, Rissoan searched for the river distance that cancels the saving in transhipment. The saved cost is used to offset the extra river cost. Afterwards, Rissoan looked for the closest inland port to the calculated river distance. The distance between the deduced Rhône-Saône port and the sea is smaller than the one calculated. Thus, a part of the saved cost can be used to offset the extra maritime cost. For this maritime distance, the extra maritime cost is equal to the remaining transhipment savings. Thus, the two distances are estimated and the sea-river competitive navigational area is deduced.

This method is too restrictive. Sea-river vessels are not always fully loaded and the product densities change. The nautical access varies along the Rhône-Saône waterway. The maximum sea-river ship size changes with the distance from the sea. These different parameters must be taken into account. Our approach defines the sea-river competitive geographical range for diverse tonnages (according to the cargoes weight and its density) and ports.

The issue is: find the maximum competitive sea trip for a known sea-river vessel departing from a given inland port and for a given cargo.

The context:

A specific Rhône-Saône river port.

- A specific sea-river vessel.

- the constraint of saving $x \%$ in comparison with a "river + sea" transport chain

Arbitrarily, we assume that the saving cost equals $10 \%$. Shippers say that the threshold of $10 \%$ savings is a psychological milestone. A lot of transport loaders would change their logistics if they can save more than $10 \%$ with a new transport alternative. Then, we address the question: Under the constraint of saving $10 \%$ in comparison with a "river + sea" transport chain, for a specific sea-river vessel and for a specific Rhône-Saône river port, what is the maximum competitive sea trip? We define the competitive foreland of sea-river vessels operating from the RhôneSaône corridor.

Sea-river shipping efficiency is sensitive to several determinants. Its geographical range depends on: the transported tonnage, the river distance, the transhipment costs, the transport unit that is used (ship size according to the navigational restrictions), the port of call, and the product density. Varying one parameter can drastically alter the competitiveness of this transport mode.

Some of them are crucial:

$\checkmark$ The product type. Our results suggest that this is probably the most important variable. The product density determines the transportable tonnage or cargo for any particular sea-river vessel. It also determines the transhipment cost (between river and maritime units) and hence the level of the potential saving cost.

$\checkmark$ The inland transport mode and the inland distance: these two variables determine the extra inland cost level. In our analysis, we place sea-river in competition with the cheapest of the three land alternatives: river transport.

$\checkmark$ The inland waterway characteristics: this parameter is relevant if the waterway is not homogenous.

Along the Rhône and the Saône, sea-river hauling capacities are disparate: 2,500 tons in Arles; 1,500 tons in Lyon and 1,300 tons in Chalon, due to the navigational restrictions on rivers and canals (length, height, draught and breadth). Unlike the river transport units, the Rhône-Saône basin resembles a funnel for sea-river ships. The longer the inland journey, the more restrictive the nautical access - sea-river transport capacity decreases - for a maximum sized sea-river ship (specially for the Rhône-Saône waterway), the problem of unused capacity affects its competitiveness. If the transport capacity does not change, the extra river cost increases with distance. By reducing the transport capacity, the sea-river cost per ton on the river segment grows faster with distance. Indeed, the numerator (fixed + variable costs) increases proportionally with the river distance while the denominator (transported tonnage) decreases. Hence the extra river cost increases more quickly (with distance) than when capacity is constant. Therefore, in order to preserve the sea-river cost advantage, sea-river ships' maritime journeys have to be reduced. 
For each transport chain we consider different transport units whose technical characteristics are summarised in Table 4. These different transport units are representative of the sea-river and river fleets on the Rhône-Saône inland waterway. The maritime transport unit (a coaster) represents a part of the Mediterranean shortsea offer.

Table 4: Transport units technical charasterictics.

\begin{tabular}{|c|c|c|c|c|c|c|c|c|}
\hline \multirow[b]{3}{*}{ Vessel type } & \multirow{2}{*}{\multicolumn{3}{|c|}{ Sea-river shipping }} & \multicolumn{5}{|c|}{ "River + Sea" transport chain } \\
\hline & & & & \multicolumn{2}{|c|}{ River transport } & \multicolumn{3}{|c|}{ Maritime transport } \\
\hline & SR1 & SR2 & SR3 & Self propeller & Push convoy & $\mathrm{DBC} 1$ & $\mathrm{DBC} 2$ & DBC3 \\
\hline Length overall & 80.0 & 85.0 & 99.0 & 100.0 & 180.0 & 100.0 & 115.0 & 140.0 \\
\hline Bean & 11.4 & 11.4 & 11.4 & 11.4 & 11.4 & 16.0 & 18.0 & 19.0 \\
\hline Draft fully laden & 3.6 & 3.7 & 3.9 & 3.2 & 3.9 & 6.0 & 8.0 & 9.0 \\
\hline Deadweight tonnage (dwt) & 1300 & 1500 & 2500 & 2000 & 4400 & 3000 & 6000 & 8000 \\
\hline
\end{tabular}

SR: Sea-River vessel.

DBC: Dry Bulk Cargo.

We voluntarily limit the maritime ship size. The largest ship deadweight is "only" 8,000 tons. This equates to a 400 - 500 TEU ship size. Far larger ships are being used in intra-Mediterranean trades, up to 1,000.TEU or above. In fact we limit the maritime ship size because inland transport unit size is restricted. However, on the maritime segment, ship-owners can obtain a lowest total cost per cargo ton by using a larger ship from DBC1 to DBC3. The maritime units are representative of the Mediterranean coaster fleet.

In order to deduce the competitive geographical range of sea-river shipping, we compare the costs of each transport chain. A cost analysis will be provided in another study. The cost of time spent in ports (for each transport chain) is included in the analysis. We examine the competitive navigational area of sea-river shipping for three inland ports and for different transhipment costs:

x Arles: the lower Rhône. Arles is the most important sea-river port of the Rhône-Saône basin. Its traffic represents $1 / 4$ of the total sea-river volumes on the Rhône-Saône waterway. It is also the inland port nearest to the sea. Both the geographical position and the nautical access make Arles competitive. Every kind of sea-river vessel (fully laden) can serve this port.

× Lyon: the middle Rhône. Lyon is a significant sea-river port. Its hinterland includes an important industrial region. Its nautical access limits the ship's hauling capacities. SR2 and SR1 can be fully loaded, but SR3 is partly loaded (about 1,500 tons against a transport capacity of 2,500 tons).

* Chalon: the upper Saône. Chalon is the most distant port from the sea. This port is a cereal platform. Sea-river transports connect the Burgundy market with the Mediterranean. The nautical access is the least favourable. Only the SR1 vessel can be fully loaded. The hauling capacities of the other sea-river ships are restricted, to approximately 1,300 tons.

The river transport capacities are uniform along the Rhône and the Saône. Irrespective of the port served, each river transport unit can be fully loaded: 2,000 tons for the self-propeller and 4,400 tons for the push convoy.

For all calculations of the competitive sea-river navigational area, we consider that the product density equals one. In addition, we consider an "average" transhipment cost of 6 euros per ton. The handling costs at the beginning and at the end of both transport chains are not taken into account. Indeed, for both transport chains, these costs (in river and maritime ports - departure/arrival ports) are similar. 


\subsection{Competitive geographical range of sea-river shipping departing from Arles:}

Arles is the most important sea-river port on the Rhône-Saône waterway. When the product density equals one and the transhipment (between river and maritime units) cost is 6 euros per ton, the SR3 can serve the entire Mediterranean market (see map 1). Each curve indicates for any particular tonnage, the maximum competitive sea trip that the SR3 can do, under the constraint of saving $10 \%$ in comparison with the "river + sea" transport chain.

We treat the first curve (900 tons and $400 \mathrm{~km}$ ): if the SR3 transports 900 tons, the maximum sea journey that it can do, under the constraint of saving $10 \%$ in comparison with the "river + sea" services, is 400 kilometres.

When the transported tonnage increases (up to the limits of carrying capacity) the SR3 competitive navigational area increases.

Map 1: SR3 competitive geographical range departing from Arles (transhipment cost 6 euros and density: 1).

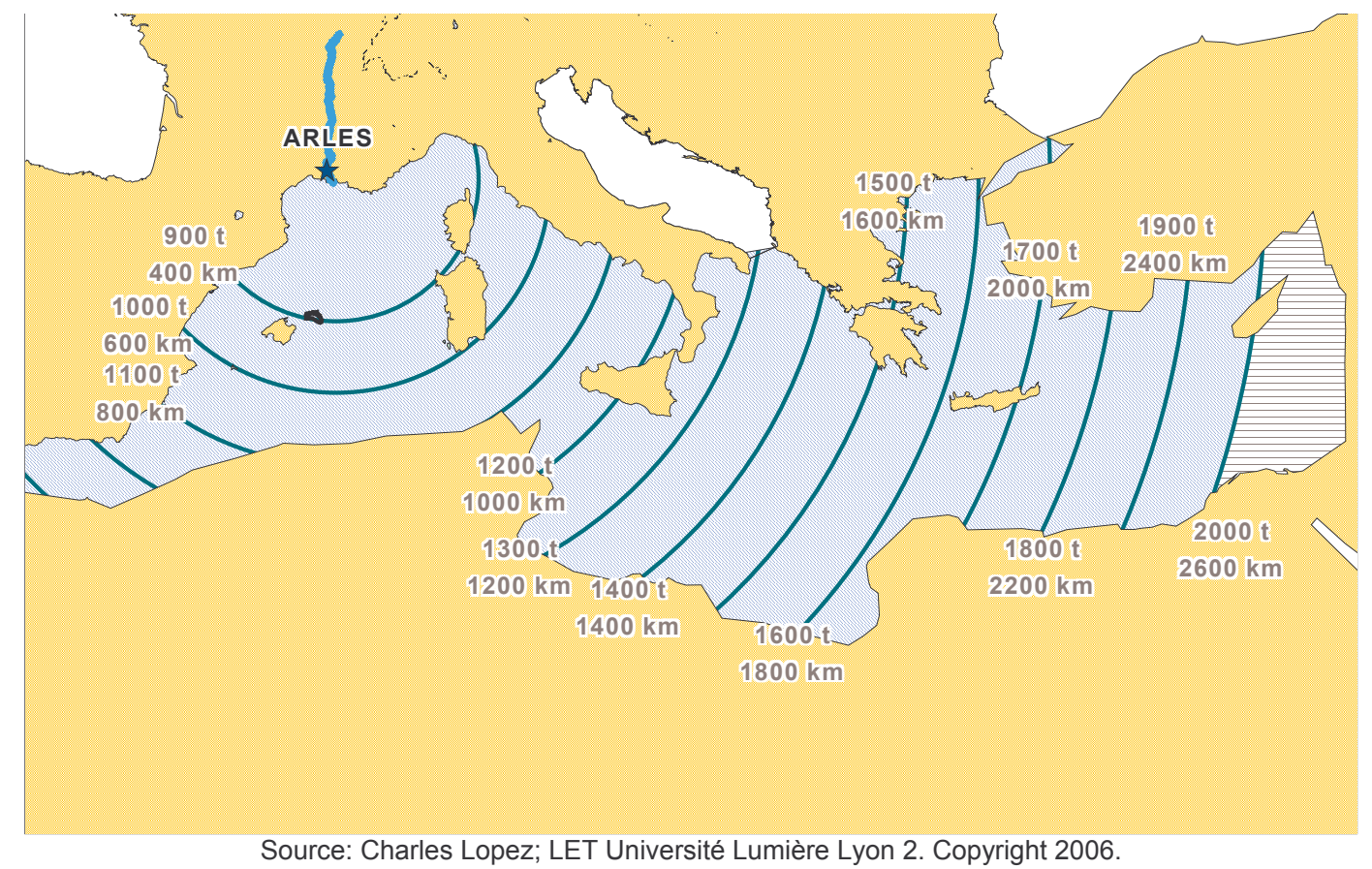

Above 2,000 tons, there is a "rupture of scale" (the zone shaded horizontally). We pass from the self-propeller to the push convoy, which is not fully loaded. At these tonnages the SR3's competitive range increases sharply. From 2,000 to 2,500 tons the maximum competitive sea trip for the SR3 exceeds the Mediterranean's geographical limits.

If the transhipment cost equals 3 euros per ton (map 2), the SR3 competitive navigational area decreases. When SR3 is fully loaded (a 2,500 tons cargo), it can serve Greece.

If the SR3 transports 2,500 tons the maximum sea journey, that it can do, under the constraint of saving $10 \%$ in comparison with the "river + sea" services, is 1,700 kilometres. 
Map 2: SR3 geographical range departing from Arles (transhipment cost 3 euros per ton and density: 1).

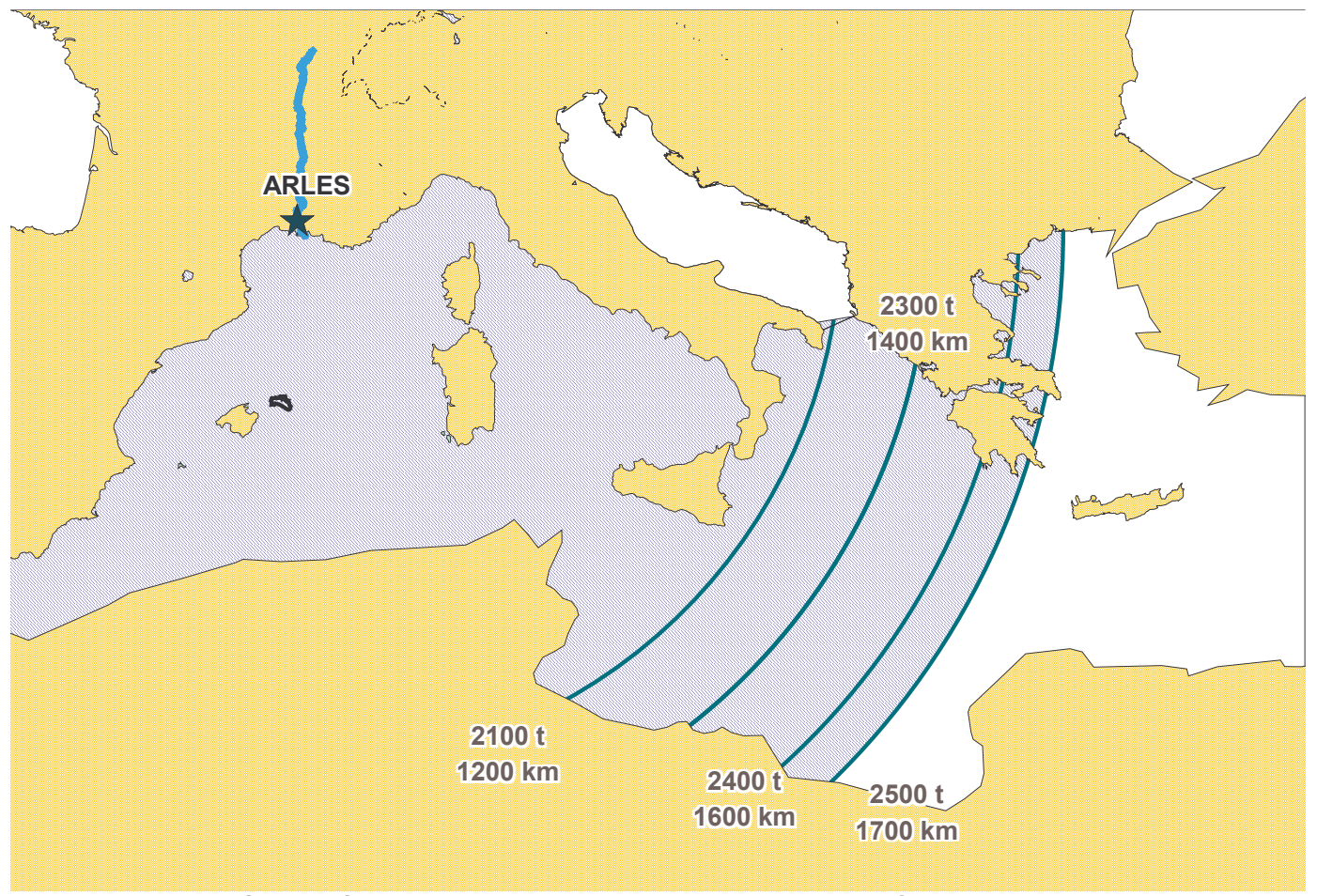

Source: Charles Lopez; LET Université Lumière Lyon 2. Copyright 2006.

\subsection{Competitive geographical range of sea-river shipping departing from Lyon:}

Map 3: SR3 competitive geographical range departing from Lyon (transhipment cost 6 euros per ton and density: 1).

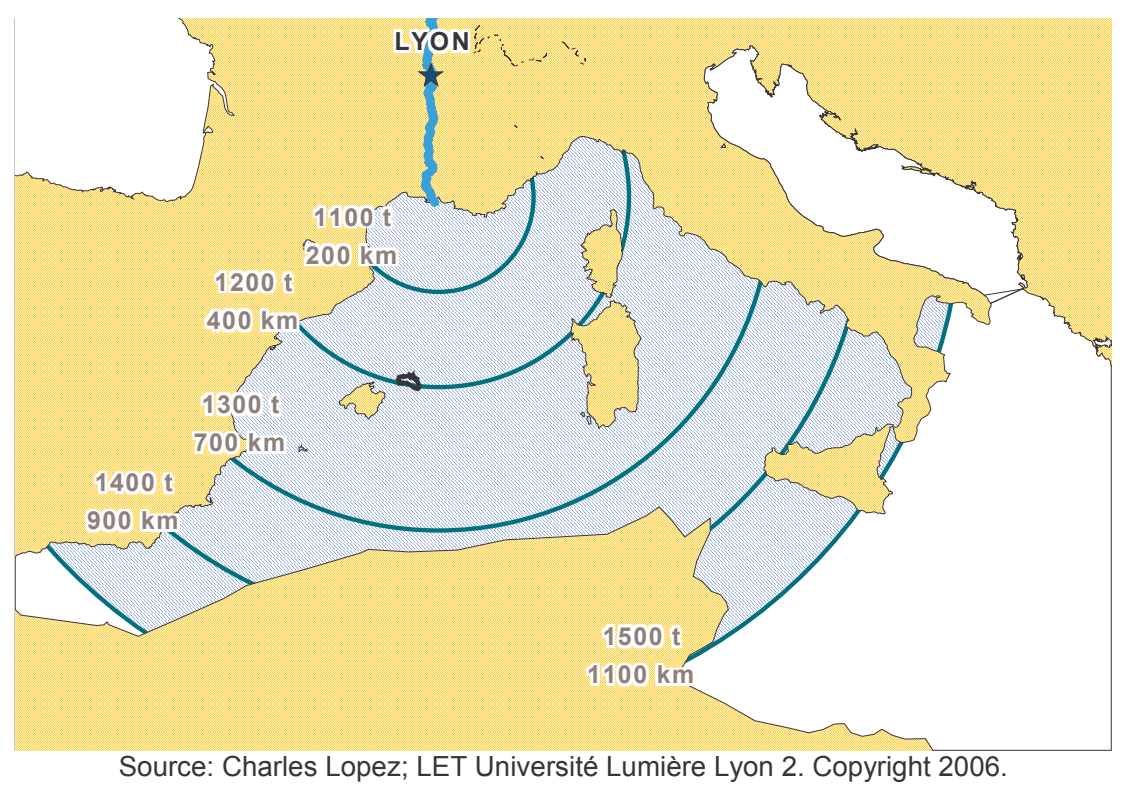

In contrast with Arles, the hauling capacity departing from Lyon is smaller. The inland infrastructure limits ship size. The SR3 is partly loaded (1,500 tons against 2,500 tons). The extra river costs are greater: there are unused capacities and the river distance is increased. Therefore, the SR3 competitive navigational area is reduced. Transporting 1,500 tons, the maximum competitive sea distance, under the constraint of saving $10 \%$, is 1,100 kilometres. In contrast, for this tonnage departing from Arles, the maritime distance is approximately 1,600 kilometres (see map.1). The SR3 is not the sea-river vessel best suited to operating from Lyon. 
Departing from Lyon, the SR2 will be used. The geographical range includes almost the whole Mediterranean market (see map 4).

Map 4: SR2 competitive geographical range departing from Lyon (transhipment cost 6 euros per ton and density: 1).

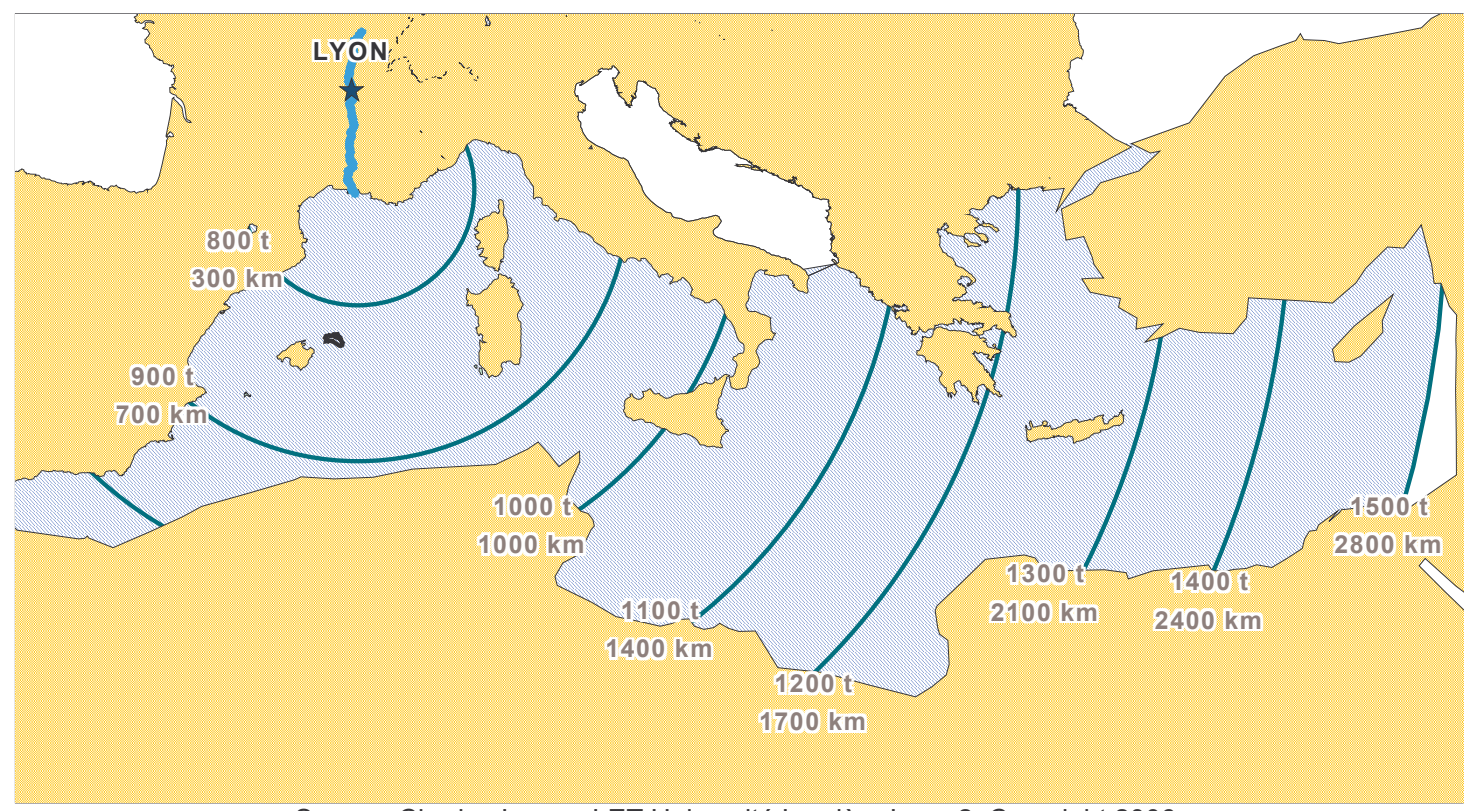

Source: Charles Lopez; LET Université Lumière Lyon 2. Copyright 2006.

If we reduce the transhipment cost, now 4 euros per ton, the sea-river competitive range decreases (see map. 5).

Map 5: SR2 competitive geographical range departing from Lyon (transhipment cost 4 euros per ton and density: 1).

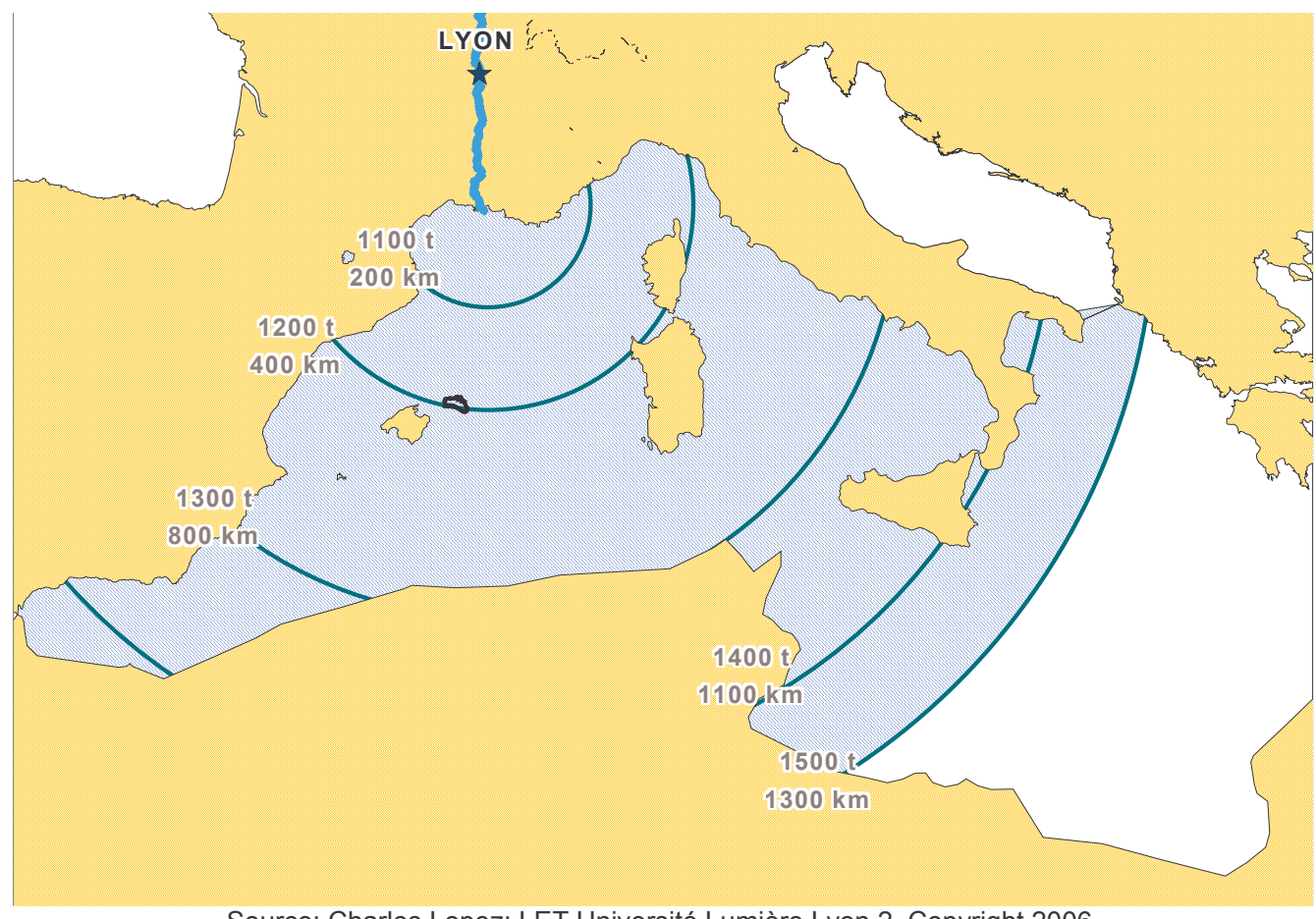

Source: Charles Lopez; LET Université Lumière Lyon 2. Copyright 2006. 


\subsection{Competitive geographical range of sea-river shipping departing from Chalon sur Saône:}

Map 6: SR1 competitive geographical range departing from Chalon (transhipment cost 6 euros per ton and density: 1).

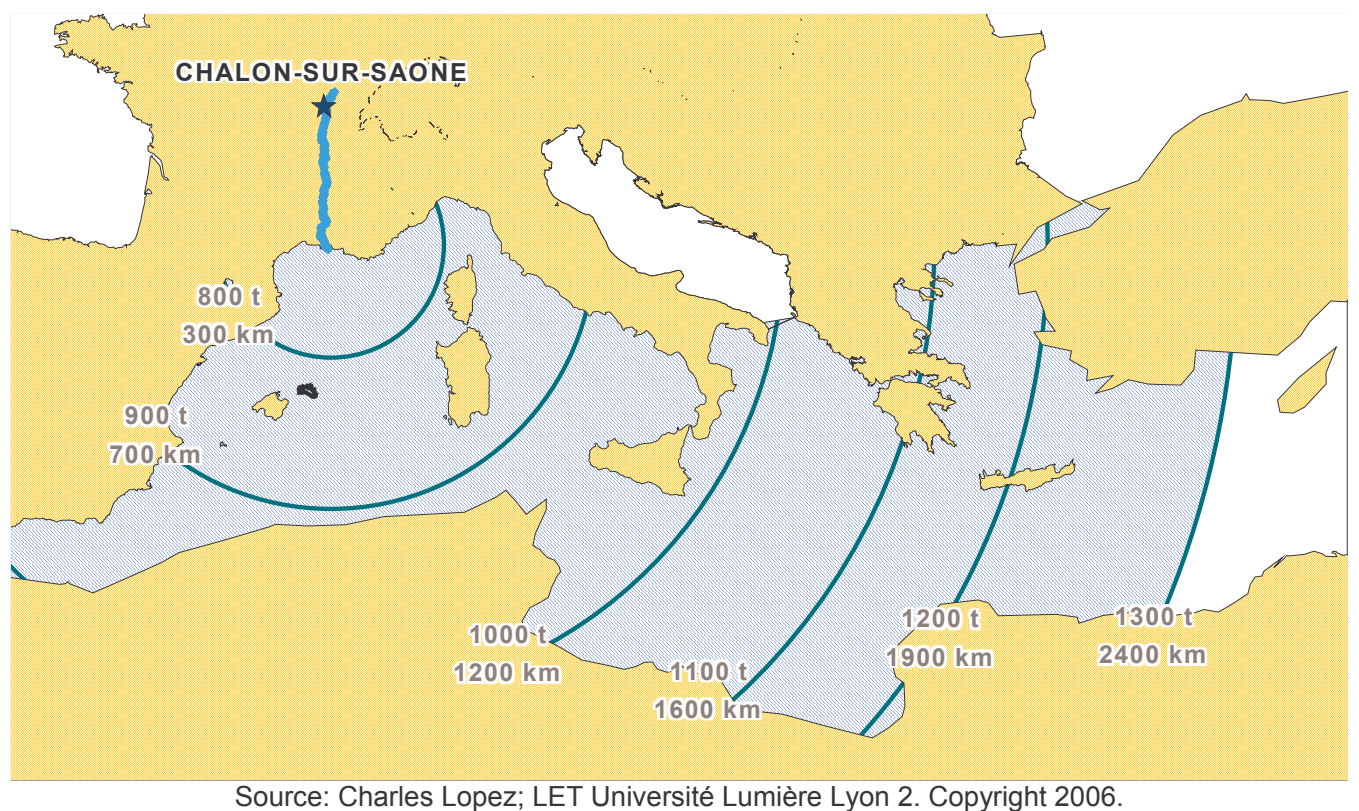

Chalon offers the most restricted nautical access and is the inland port the most distant from the sea. The sea-river vessels' carrying capacity is limited to 1,300 tons. The extra river costs are the greatest. The SR3 competitiveness is close to zero. The SR1 is the best suited to operating from this cereal platform. In spite of these conditions, the SR1 competitive geographical range covers most of the Mediterranean market (see map.6). It is so large because the "river + sea" transport units are not fully loaded. This waste of capacity creates the SR1 comparative efficiency.

Now, if we reduce the transhipment cost, reducing from 6 to 4 euros per ton, the SR1 competitive navigational area decreases sharply (see map.7). The extra river cost is almost equal to the saved transhipment.

Map 7: SR1 competitive geographical range departing from Chalon (transhipment cost 4 euros per ton and density: 1).

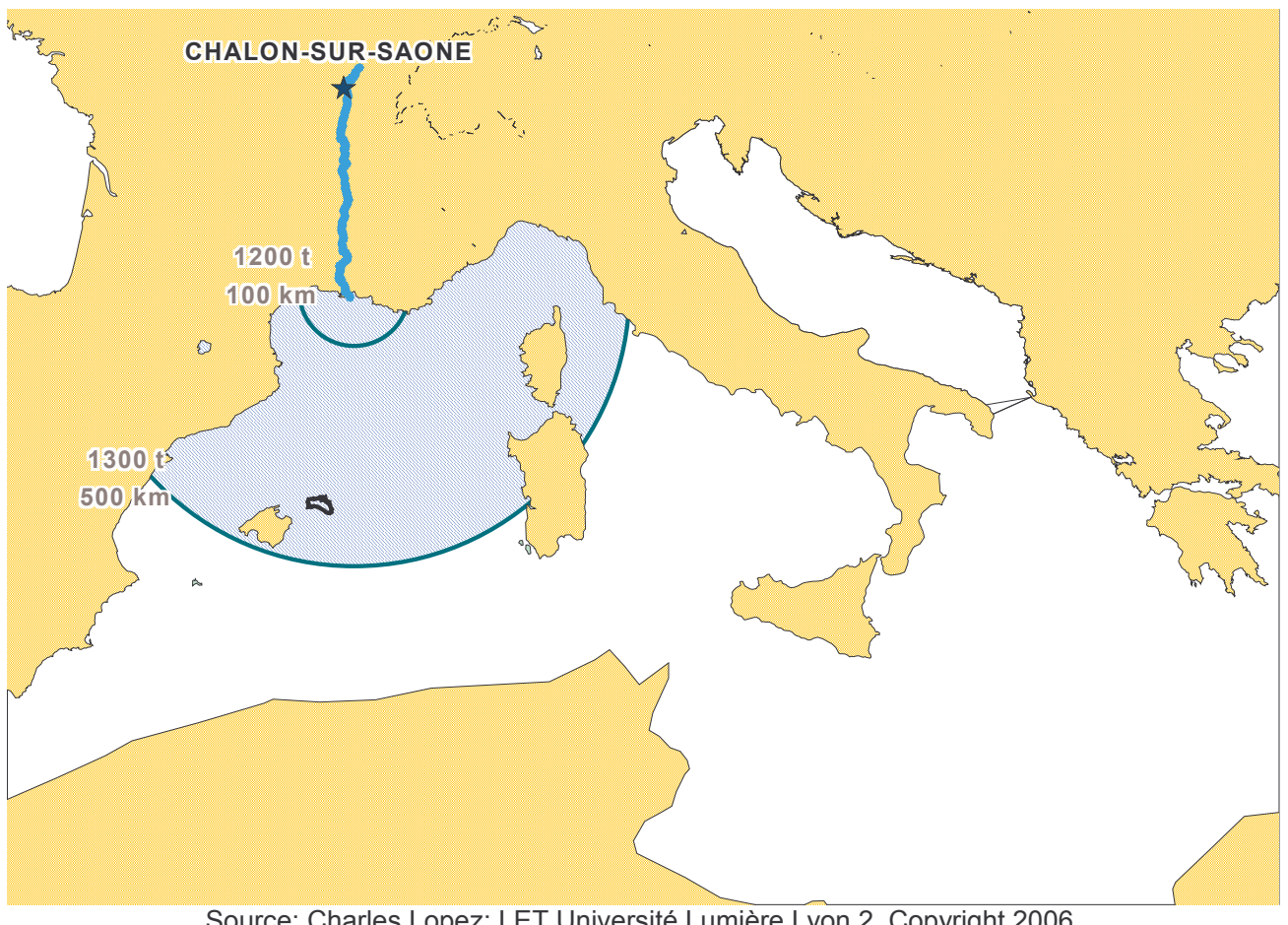

Source: Charles Lopez; LET Université Lumière Lyon 2. Copyright 2006. 


\section{CONCLUSION}

In search for a competitive advantage, over recent decades the maritime transport has seen a spectacular increase in ship size. In response, ports and terminals have to make large and rapid investments in infrastructure to cope with these new vessels. While ship size is increasing we develop a model that quantifies the economies of scale in operating diverse transport units. This facilitates the evaluation of the sea-river shipping competitiveness. Sea-river shipping is particularly interesting for ports that can only operate small cargoes. It is very interesting for feeder services. It can provide intermodal door-to-door transports.

Today, the annual sea-river traffic on the Rhône-Saône corridor is of the order of one million tons. A large part is attributed to the export of cereals (approximately one third of the total volume). However, this is quite small in comparison with the 5.6 million tons transported by river units

The sea-river competitive geographical range covers the western Mediterranean including the Maghreb (Algeria, Morocco and Tunisia). In 2005, European countries (EU members) and the Maghreb are the most important destinations of sea-river vessels operating on the Rhône-Saône basin (more than $90 \%$ of the annual tonnage). Italy and its islands (Sardinia and Sicily) are the primary trading partners (55\% of the annual traffic).

Sea-river has a market niche for small volumes. This is an attractive solution for heavy goods whose handling is expensive and complex. Sea-river shipping is particularly interesting for smaller Mediterranean ports. "River + sea" services are left to transport large cargoes, especially to the main Mediterranean seaports. Therefore, the two transport chains are complementary.

The sea-river market niche is very restricted. On the Rhône-Saône waterway, the sea-river activity is not constant. It is strongly dependent on cereal traffic. The traffic is not well balanced as exports exceed imports. The captive fleet (vessels which made more than 20 journeys on the Rhône-Saône corridor), in 2005, consists of just 8 ships. The ageing of the fleet raises the issue of fleet renewal, security and reliability. In addition the problem of unused capacity on return journeys (from the Mediterranean) and of increasing costs (due in part to the sharp rise in fuel price) affect sea-river transport's competitiveness. This raises the question: what kind of actions can help to ensure the future of sea-river transport on the Rhône-Saône waterway? These could be financial assistance, regulatory reforms and/or technical innovations.

Sea-river competitiveness is limited by several navigational restrictions on rivers and canals (draught in particular, length...). Konings and Ludema (2000) have evaluated the possibility of developing a new sea-river transport system. The river-sea push barge (or RSPB) is able to circumvent the restrictions mentioned above. Vecomar International and Marine Heavy Lift Partners in Netherlands developed the technical design of the RSPB concept: specially designed push barges that can be used on inland waterways and also at sea. These barges can adjust to different draught conditions in an optimal way. On the inland waterway, the barge is pushed by a conventional (river) pusher tug. For the sea trip a special tug (warranted as seaworthy) is linked to the barge with an Arti-couple system. The barge's ballasts give the barge the required draught for its sea passage. The operational processes can be broken into three sections. "The river push boat sails the barge from the hinterland into the seaport, where a change of push boat takes place. Next the seagoing push boat sails the barge to the destination seaport". According to the authors, the interchange of push boats in the seaport is fast (maximum 2 hours). The RSPB system avoids seaport transhipment and optimises barges' carrying capacities according to the river infrastructure. This technical innovation can be transferred to the Rhône-Saône waterway and could ensure the future of sea-river shipping.

Freight transport is growing every year in Europe. Policy makers search for alternative transport systems that avoid significant bottlenecks with negative effects on the economy. Sea transport, and short-sea shipping in particular, provide an effective alternative to bypass natural barriers, such as the Alps and Pyrenees. The European Commission introduced the concept of "motorways of the sea" in its 2001 Transport White Paper, underlying that it is "a real competitive alternative to land transport". The proponents of the "motorways of the sea" hope to break down the barriers between transport modes, by organising and making a better use of our existing transport resources. Sea-river shipping can complete short-sea shipping services by offering "Rhône valleyMediterranean" logistics (linking the Rhône-Saône waterway with the Mediterranean).

The IBERLIM ${ }^{3}$ project aims to establish in 3 years time, an economically viable and sustainable sea-river shipping service between the Iberian Peninsula and Limay in France via the Atlantic Arc. This route is identified by the European Commission as one of the "Motorways of the Sea". This transport route is an alternative to the roads and bypasses the Pyrenees. Existing northbound road freight transport streams are shifted towards sea-river

${ }^{3}$ Acronym name that means the link between Iberian Peninsula and the port of Limay. 
vessels. The French port of Limay (on the Seine) is directly connected with the Portuguese ports of Figueira da Foz, Setubal and Ribadeo. The environmental (\& social) benefit for this modal shift action is 20.2 million euros ${ }^{4}$. This kind of project can be developed on the Rhône-Saône corridor.

A shipper's choice of transport depends on numerous considerations. The most cited are: cost, time, reliability and prevention of damage. In examining the competitiveness of sea-river shipping by using microeconomic theory, we concentrate on the costs and economies of scale. We can complete this study by including the factors mentioned above and external costs into the model. In conclusion sea-river shipping could give a new dimension and opportunities to develop intermodal transport in Europe.

\section{Acknowledgements:}

I am very grateful to the editor, Professor Richard Knowles, and two anonymous referees for their observations, constructive criticism and helpful suggestions, which have significantly improved this paper.

4 Source: NAVEIRO - Transportes Maritimos - Portugal in Presentation of the Iberlim project - Marco Polo conference November 2006 - http://ec.europa.eu/transport/marcopolo/highlights/index_en.htm 


\section{REFERENCES.}

Bain, J., 1956. Barriers to New Competition. Cambridge Mass. Harvard University Press.

- Benford, H., 1968. General Cargo Ship Economics and Design. College of Engineering of Michigan.

- Charlier, J., Fohal, J. 2005. Le transport fluviomaritime a' I'heure des autoroutes de la mer. L'exemple de l'avant-pays nautique des ports de Bruxelles, Duisbourg, Liège et Paris. Travail subsidie' par la Région de Bruxelles-Capitales (Prospective Research for Brussels 2002).

- Cullinane, K.P.B., Khanna, M., 1999. Economies of scale in large containerships. Journal of Transport Economics and Policy 33 (2), 185-208.

- Cullinane, K.P.B., Khanna, M., 2000. Economies of scale in large containerships: optimal size and geographical implications. Journal of Transport Geography 8, 181-195.

- Drewry Shipping Consultants, 1996. Post-Panamax Containerships: 6000 TEU and beyond, Drewry Shipping Consultants, London.

- Erichsen, S., 1971. Optimum Capacity of Ships and Port Terminals. College of Engineering of Michigan.

- Getz, J.R., Erichsen, S., Heirung, E., 1967. Design of a Cargo Liner in Light of the Development of General Cargo Transportation. Society of Naval Architects and Marine Engineers.

- Gilman, S., 1980. Ship Choice in container Age. Marine Transport Center, Liverpool.

- Gilman, S., 1983. The Competitive Dynamics of Liner Shipping. Gower, Aldershot.

- Gilman, S., 1999. The Size Economies and Network Efficiency of Large Containerships. International Journal of Maritime Economics 1 (1), 39-59.

- Goss, R.O., Jones, C.D., 1971. The Economies of Size in Dry Bulk Carriers. H.M. Stationery Office.

- Goss, R.O., 1974. Cost of Ships Time, London, Government Economic Service Occasional Papers.

- Heaver, T., 1968. The Economies of Vessel Size: a Study of Shipping Costs and their Implications for Port Investments. National Harbours Board, Ottawa.

- Jansson, J.O., Schneerson, D., 1982. The optimal ship size, Journal of Transport Economics and Policy, September 1982.

- Jansson, J.O., Schneerson, D., 1987. Liner Shipping Economics. Chapman and Hall, London.

- Konings, R., Ludema, M., 2000. The competitiveness of river-sea transport system: market perspectives on the United Kingdom-Germany corridor. Journal of Transport Geography 8, 221-228.

- $\quad$ Lim, S.-M., 1994. Economies of ship size: a new evaluation. Maritime Policy and Management 21 (2), 149166.

- Marcadon, J., 1986. Le concept d'avant-pays marin: approche méthodologique. Ports et Mers, Mélanges maritimistes offerts à André Vigarié. J. Charlier (éd), Paradigme, Caen, 47-57.

- McKinsey and Co. Inc., 1967. Containerisation; Key to Low Cost Transport, London British Transport Docks Board.

- McLellan, R.G., 1997. Bigger vessels: How big is too big? Maritime Policy and Management 24 (2), 193211.

- Pearson, R., 1988. Container Ships and Shipping. London Fairplay Publication, Fairplay.

- Review of maritime transport 2005, CNUCED, New York and Geneva 2005.

- Rissoan, J.P., 1987. Le Rho^ne et la mer. La navigation fluvio-maritime rhodanienne, Lyon, Institut des études rhodaniennes de Lyon.

- Rissoan, J.P., 1994. River-sea navigation in Europe. Journal of Transport Geography 2 (2), 131-142.

- Rissoan, J.P., 1995. La navigation fluvio-maritime et la vie régionale en Europe, the se pour le doctorat d'Etat es-Lettres, Lyon.

- Rodrigue, J.-P., Comtois, C., Slack, B., 2006. The Geography of Transport Systems. Routledge, London.

- Ryder, S.C., Chapell, D., 1979. Optimal Speed and Ship Size for Liner Trades, Liverpool, Marine Transport Center. University of Liverpool.

- Stopford, M., Is the drive for ever-bigger containership irresistible, Lloyds List Shipping Forecasting Conference, 26th April 2002.

- $\quad$ Talley, W.K., 1990. Optimal Ship Size. Maritime Policy and Management 17, 165-175.

- Thoburn, T., 1960. Supply and Demand for Water Transport, Business Research Institute, Stockholm School of Economics.

- Tozer, D., 2003. Ultra-large container ships: the green ships of future, Shipping World and Shipbuilder, October 2003.

- Tozer, D., Penfold, A., 2001. Ultra-large container Ships (ULCS), 2002. Designing to the limit of current and projected terminal infrastructure capabilities. Lloyd's Register Technical Association Paper No. 5, session $2001-$ 2002.

- Tozer, D., Penfold, A., 2000. Container ships: Design aspect of larger Vessels, Lloyd's Register and Ocean Shipping Consultants Ltd, RINA/Imare presentation, London, March 2000.

- Wijnolst, N., Scholtens, M., Waals, F., 1999. Malacca-Max: The Ultimate Container Carrier - Design Innovation in Container Shipping. Delft university press. 